\title{
Effect of solar ultraviolet radiation on bacterio- and phytoplankton activity in a large coral reef lagoon (southwest New Caledonia)
}

\author{
Pascal Conan ${ }^{1,2, *}$, Fabien Joux ${ }^{1,2}$, Jean-Pascal Torréton ${ }^{3}$, Mireille Pujo-Pay ${ }^{1,2}$, \\ Thierry Douki ${ }^{3,4}$, Emma Rochelle-Newall $^{3}$, Xavier Mari ${ }^{5}$ \\ ${ }^{1}$ Université Pierre et Marie Curie - Paris 6 (UPMC) and ${ }^{2}$ CNRS, UMR 7621, LOBB, Observatoire Océanologique, \\ Banyuls-sur-mer 66651, France \\ ${ }^{3}$ IRD UR103, ECOLAG/UMR 5119, Université Montpellier II, Case 093, 34095 Montpellier Cedex 05, France \\ ${ }^{4}$ Laboratoire Lésions des Acides Nucléiques, UMR-E CEA-UJF, CEA/DSM/Département de Recherche \\ Fondamentale sur la Matière Condensée, 38054 Grenoble Cedex 9, France \\ ${ }^{5}$ IRD UR103, Nouméa Center, BP A5, 98848 Nouméa, New Caledonia
}

\begin{abstract}
Measurements of underwater solar ultraviolet radiation (UV-R, 280 to $400 \mathrm{~nm}$ ), particulate (PPP) and dissolved (DPP) primary and bacterial (BP) production allowed us to infer the respective contribution of UV-B (280 to $315 \mathrm{~nm}$ ) and UV-A (315 to $400 \mathrm{~nm}$ ) in algal-bacterial interactions in the southwest lagoon of New Caledonia. Differences in and between activities were assessed by in situ exposure of plankton to full sun radiation and shielded for UV-B or UV-R. We found a coherent response of phytoplankton and bacteria in total UV-R inhibition. The deepest limit of UV-R influence was $8 \mathrm{~m}$, and inhibition increased with oligotrophy to reach $55 \%$ for phytoplankton and $75 \%$ for bacteria, at $1 \mathrm{~m}$ depth. UV-B contributed up to $50 \%$ to the inhibition, especially near the surface and at the oligotrophic station. The UV-A effect on PPP was stronger than that of UV-B; however, bacteria were more sensitive to UV-B than were phytoplankton. When considering UV-A and UV-B separately, the inhibition response was linear without threshold. However, a threshold of 0.002 for PPP and 0.004 for BP was obtained when considering the ratio UV-B:UV-A. The rate of PPP normalized to chlorophyll concentration ( $\mathrm{PP}^{\mathrm{chl}}$ ) is proposed to reconcile the large range of inhibition encountered in the literature. A significant linear relationship predicted a PPP inhibition of $60 \%$ in surface water with no significant effect on excretion for cells characterized by a low PP ${ }^{\text {chl }}$, whereas PPP inhibition should be limited for cells characterized by a $\mathrm{PP}^{\mathrm{chl}}$ higher than $18 \mathrm{mg} \mathrm{C}(\mathrm{mg} \mathrm{chl})^{-1} \mathrm{~h}^{-1}$, even if excretion (DPP) could be slightly stimulated.
\end{abstract}

KEY WORDS: Ultraviolet radiation $\cdot \mathrm{UV}-\mathrm{A} \cdot \mathrm{UV}-\mathrm{B} \cdot$ Bacterioplankton $\cdot$ Phytoplankton $\cdot$ Productivity Inhibition · DNA damage

\section{INTRODUCTION}

It is now widely documented that solar ultraviolet radiation (UV-R; 280 to $400 \mathrm{~nm}$ ), i.e. UV-B ( 280 to $315 \mathrm{~nm}$ ) and UV-A (315 to $400 \mathrm{~nm}$ ), is detrimental to various forms of life in the upper layer of aquatic ecosystems (i.e. De Mora et al. 2000, UNEP 2006). This biologically damaging mid-ultraviolet radiation can penetrate to ecologically significant depths in aquatic systems (Tedetti \& Sempéré 2006). In fact, UV-R has complex and antagonistic effects that are both direct and/or indirect (Villafãne et al. 2004). Briefly, UV-R affects DNA, proteins and lipids by producing reactive oxygen species (Vincent \& Neale 2000), whereas UV-B radiation 
impairs genetic material through the production of pyrimidine-pyrimidone (6-4) and cyclobutane-pyrimidine dimers (Gieskes \& Buma 1997).

Microbial communities have evolved a variety of repair and protective mechanisms associated with high solar radiation. However, a potential increase in UV-R due to climate modification in aquatic ecosystems could affect adaptive strategies, impair important physiological functions and threaten marine organisms during their developmental stages (e.g. especially larvae forms). UV-R damage at the molecular, cellular, population and community levels has been widely documented on photosynthetic rate, nitrogen metabolism (Fouilland et al. 2003), reproduction, growth rate, motility (Nielsen \& Ekelund 1995), orientation and floatability (Mostajir et al. 1999).

The effects of UV-R on production, abundance and survival of aquatic heterotrophic bacteria are also well documented (see Jeffrey et al. 2000 for review). UV-R reduces not only primary (PP) and bacterial production (BP) but also inhibits the activities of their predators, interrupts the trophic transfer of matter and energy towards higher levels and, thus, channels more carbon into the microbial food web (Wängberg et al. 1998). Reduced biomass production, changes in species composition and biodiversity and alterations of biogeochemical cycles are also potential impacts of UV-R in aquatic ecosystems. In fact, more attention should be paid to the variability of UV-R effects in relation to environmental conditions and between the different compartments of the ecosystem in order to discriminate the impacts of various, and sometimes antagonistic, factors. For this purpose, we used an in situ approach focused on bacterial and phytoplankton activity along a trophic gradient. To our knowledge, the present study is the first of its kind to consider simultaneous measurements of phytoplankton and bacterial activity at a daily scale throughout the water column.

The southwest lagoon of New Caledonia is a semienclosed, relatively shallow site $(\sim 20 \mathrm{~m})$ covering ca. $2066 \mathrm{~km}^{2}$ and surrounded by oligotrophic oceanic water of the Coral Sea. Owing to its geographical location, and the range of trophic conditions encountered, this site is particularly well suited for in situ UV-R studies. Trophic conditions in the southwest lagoon vary from severe oligotrophy near the coral barrier to mesotrophic conditions in the near-shore environment subject to terrestrial inputs and, around the city of Nouméa (146000 inhabitants), to both industrial and urban effluent. This results in well-defined gradients of eutrophication that are relatively constant throughout the year (Jacquet et al. 2006) and are strengthened by gradients of the water mass residence time (Jouon et al. 2006, Torréton et al. 2007).
The aim of the present study was to measure the effects of UV-R and the relative contribution of UV-A and UV-B to PP and BP simultaneously along a trophic gradient and at different depths in the water column. The present study provides an evaluation of the spectral composition of solar radiation in algal-bacterial interaction along a trophic gradient as well as information about the irradiance penetration in different types of water.

\section{MATERIALS AND METHODS}

Study sites and water sampling. In situ exposure experiments were conducted in the southwest lagoon of New Caledonia ( $22^{\circ} 00$ to $30^{\prime} \mathrm{S}, 166^{\circ} 00$ to $30^{\prime} \mathrm{E}$ ) in November and December 2004 at 3 stations located along a coastal offshore gradient in the lagoon (Fig. 1). Vertical profiles were carried out with a CTD probe (Seabird SBE 25). Seawater (prefiltered through a $200 \mu \mathrm{m}$ pore size mesh) containing natural plankton populations were collected at sunrise (between 06:00 and 8:00 h) from $5 \mathrm{~m}$ depth at each station using a $5 \mathrm{l}$ Niskin bottle for nutrient and dissolved organic matter (DOM) determination and for incubation experiments. All measurements were made in triplicates except for ammonium $\left(\mathrm{NH}_{4}\right)$ and dissolved organic carbon (DOC) which were determined in duplicates.

In situ incubations. In situ incubations were done at 3 depths in the water column. Water samples collected from $5 \mathrm{~m}$ depth were divided into 2 series of subsamples: one series was inoculated with ${ }^{14} \mathrm{C}$ bicarbonate for PP measurements (see below); the other one was used directly for BP measurements. For each subsample and depth, 4 radiation treatments were applied in triplicates. Treatments were (1) FS = full sun radiation (PAR [photosynthetically active radiation] + UV-R; uncovered quartz tubes), (2) PAR + UV-A = PAR and UV-A radiation, i.e. UV-B was excluded (quartz tubes covered with Mylar foil [50\% transmission at $320 \mathrm{~nm}$ ]), (3) $\mathrm{PAR}=\mathrm{PAR}$ radiation, i.e. UV-R was excluded (Pyrex tubes covered with Courtgard film [50\% transmission at $400 \mathrm{~nm}$ ]) and (4) DK = dark (Pyrex tubes covered with aluminum foil). Note that the use of different films could induce variations in the total irradiance received of up to $15 \%$ among subsamples. The tubes were fixed on 3 metal frames deployed at 1,4 and $8 \mathrm{~m}$ depths (Fig. 2). Samples were incubated for $\sim 6 \mathrm{~h}$ around 12:00 h local time.

Solar radiation measurements and biodosimeters. During incubation experiments, the underwater solar radiation was regularly measured around the station using a UV/visible spectroradiometer (Ramses, TriOS), which has a $2 \mathrm{~nm}$ resolution between 280 and $720 \mathrm{~nm}$. Intercalibration was made with an underwater radio- 


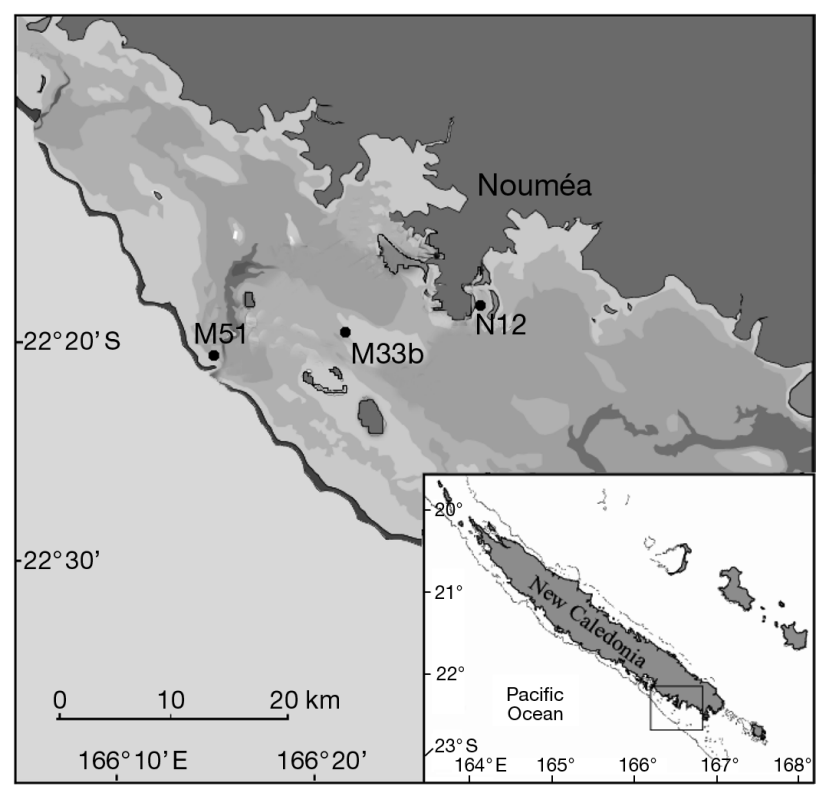

Fig. 1. Location of the 3 stations studied

meter (ELDONET; see surface radiometer version below for range description). The penetration of nearnoon solar radiation was recorded several times at the sampled station. Incident solar radiation was monitored continuously using a surface radiometer (ELDONET; Real Time Computers), installed in a shade-free area close to the experimentation site. This radiometer measured UV-B (280 to $315 \mathrm{~nm}$ ), UV-A (315 to $400 \mathrm{~nm}$ ) and PAR (400 to $700 \mathrm{~nm}$ ) with a frequency of 1 reading $\mathrm{min}^{-1}$. Total daily dose was calculated by integrating the data.

Attenuation of biologically effective UV-B radiation was studied with DNA biodosimeters. Quartz tubes filled with $2.5 \mathrm{ml}$ of DNA solution $\left(50 \mu \mathrm{g} \mathrm{ml} \mathrm{m}^{-1}\right.$ DNA Salmon testes, Sigma, in $0.1 \mathrm{M} \mathrm{NaCl}, \mathrm{pH}$ 7.2) were incubated at the same depths and during the same periods as the samples. After exposure, the biodosimeters were stored at $-20^{\circ} \mathrm{C}$ until analysis. The amounts of the different forms of cyclobutane pyrimidine dimers (CPDs) (i.e. Thy $<>$ Thy, Thy $<>$ Cyt, Cyt $<$ $>$ Thy and $\mathrm{Cyt}<>\mathrm{Cyt}$ ) were determined by high-performance liquid chromatography-tandem mass spectrometry (HPLC-MS/MS) (Douki \& Cadet 2001). Briefly, DNA was enzymatically digested by a mixture of endonucleases, exonucleases and phosphatase. Bipyrimidine photoproducts were recovered in the form of modified dinucleoside monophosphates. The mixture was separated on an HPLC column and the photoproducts quantified by online mass spectrometry analysis in the multiple reaction monitoring mode. Biologically effective attenuation coefficients $\left(K_{\text {bd-eff }}\right)$ were calculated from linear regressions of natural logarithmic

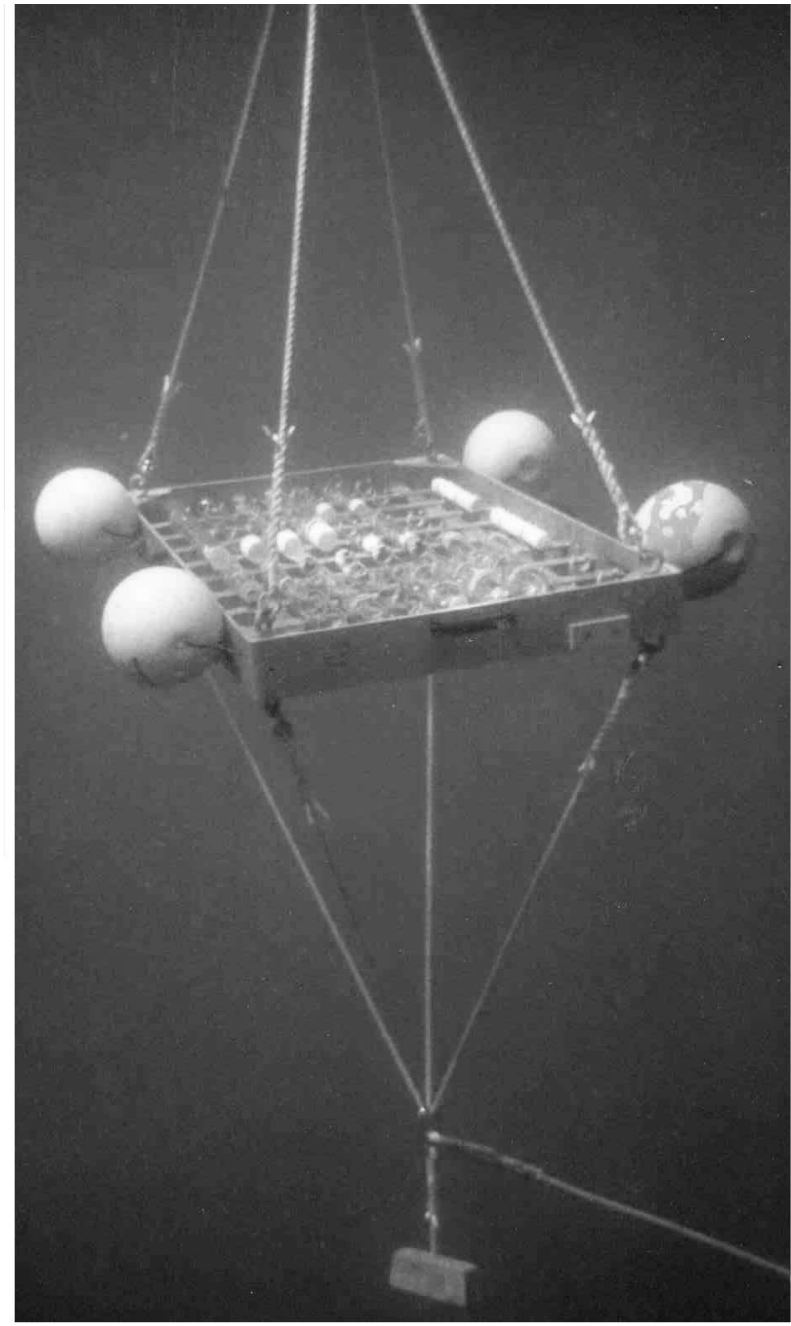

Fig. 2. In situ incubation module. (Photo: B. Hesse)

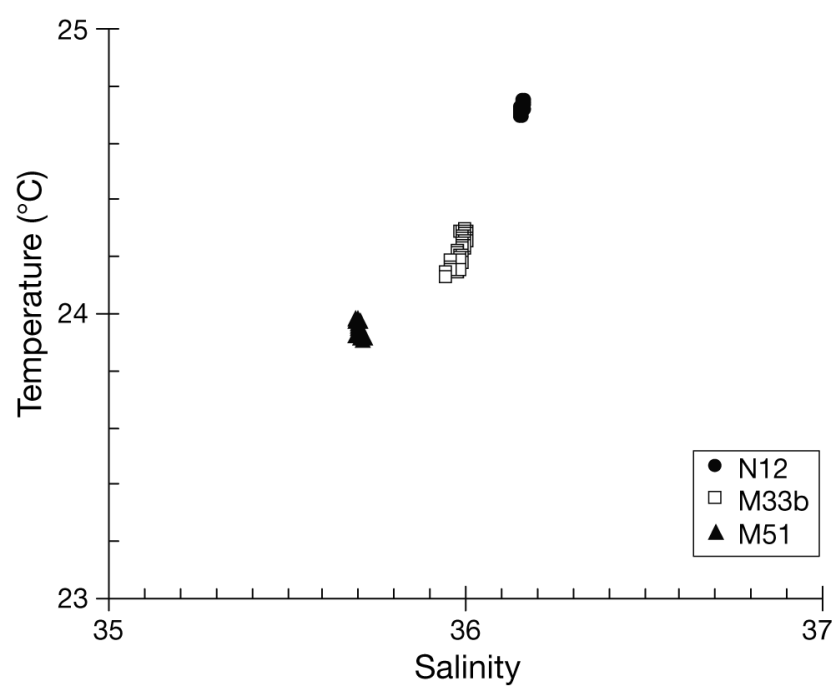

Fig. 3. Temperature vs. salinity for the 3 stations 
CPDs per million nucleotides versus depth using the ln-linear part of the curve.

Nutrients. Ammonium concentration was determined fluorimetrically on unfiltered $40 \mathrm{ml}$ replicates on a Turner TD-700, using the o-phthaldialdehyde method (Holmes et al. 1999) immediately after collection. Measurement accuracy was $\pm 0.02 \mu \mathrm{mol} \mathrm{l}^{-1}$. Subsamples for nitrate and nitrite $\left(\mathrm{NO}_{3}+\mathrm{NO}_{2}\right)$ and phosphate $\left(\mathrm{PO}_{4}\right)$ determinations were frozen $\left(-20^{\circ} \mathrm{C}\right)$ on board immediately after sampling in polyethylene bottles until further analyses in the laboratory. $\mathrm{NO}_{3}$ was reduced to $\mathrm{NO}_{2}$ according to Wood et al. (1967), and $\mathrm{NO}_{3}+\mathrm{NO}_{2}$ concentrations were determined on a Bran+Luebbe Autoanalyzer III, as well as $\mathrm{PO}_{4}$, according to Tréguer \& Le Corre (1975). Measurement accuracy was \pm 0.05 and $\pm 0.02 \mu \mathrm{mol} \mathrm{l} \mathrm{l}^{-1}$ for $\mathrm{NO}_{3}+\mathrm{NO}_{2}$ and $\mathrm{PO}_{4}$, respectively.

DOC. Precombusted $\left(24 \mathrm{~h}, 450^{\circ} \mathrm{C}\right)$ glass vials were filled with $20 \mathrm{ml}$ of subsample, poisoned with $\mathrm{H}_{3} \mathrm{PO}_{4}$ $(85 \%)$ and sealed on board for DOC determination by high temperature catalytic oxidation (HTCO) using a Shimadzu TOC-Vcph analyzer.

Colored DOM (CDOM). Water samples were filtered through $0.2 \mu \mathrm{m}$ Nuclepore filters and stored in the dark at $4{ }^{\circ} \mathrm{C}$ until analysis. The absorbance of the water samples was measured in the laboratory using a $10 \mathrm{~cm}$ quartz cuvette in a spectrometer Perkin-Elmer Lambda 20. The reference was Milli-Q water. The absorption coefficient at $350 \mathrm{~nm}$ was used as an indicator of CDOM concentration.

Chlorophyll. Total chlorophyll determination was conducted from $200 \mathrm{ml}$ subsamples filtered on board onto Whatman GF/F filters and stored in the dark at $-20^{\circ} \mathrm{C}$ until analysis. Within $24 \mathrm{~h}$, chlorophyll a concentration (and phaeophytin after acidification) was fluorimetrically determined on methanol extracts according to Holm-Hansen et al. (1965) using a TD700 fluorometer.

Bacterial, pico- and nano-phytoplankton abundances. Abundances were quantified by flow cytometry. Samples $(3 \mathrm{ml})$ were preserved with $2 \%$ final concentration of formaldehyde in cryovials, gently mixed and left in the dark at room temperature for $10 \mathrm{~min}$ before quick-freezing in liquid nitrogen and storage at $-80^{\circ} \mathrm{C}$. Before analysis by flow cytometry (FACSCalibur, Becton Dickinson), the samples were thawed at room temperature. For bacterial analysis, samples were stained with a nucleic acid dye (SYBR Green I; final concentration $0.01 \%$ vol/vol of the commercial solution; Molecular Probes) for at least $15 \mathrm{~min}$ at $20^{\circ} \mathrm{C}$ in the dark. Bacteria were detected on a plot of green fluorescence (515 to $545 \mathrm{~nm}$ ) versus right angle light scatter (SSC), using green fluorescence as the threshold parameter. Picophytoplankton cells were analyzed directly by flow cytometry. Synechococcus spp. were detected on a plot of orange fluorescence (564 to $606 \mathrm{~nm}$ ) versus SSC. Photosynthetic pico- and nanoeukaryotes were enumerated on a red fluorescence (>650 nm) versus SSC cytogram where Synechococcus were eliminated. No Prochlorococcus spp. were found in these samples. Fluorescence beads (1 $\mu \mathrm{m}$; Polysciences) were added to each sample analyzed for normalization of the fluorescence and SSC signals.

Particulate (PPP) and dissolved primary production (DPP). Carbon fixation rates were determined using the ${ }^{14} \mathrm{C}$ light and dark bottle technique as modified by Fitzwater et al. (1982). Subsamples of about 41 were inoculated with $1 \mathrm{ml}$ of the $\mathrm{Na}_{2} \mathrm{H}^{14} \mathrm{CO}_{3}$ working solution (final activity $\sim 0.10 \mu \mathrm{Ci} \mathrm{ml}^{-1}$ or $3.7 \mathrm{kBq} \mathrm{ml}^{-1}$ ). Total added activity was assayed in triplicate on a $250 \mu \mathrm{l}$ aliquot collected in a scintillation vial containing $200 \mu \mathrm{l}$ of ethanolamine. The incubation tubes (triplicate per light condition) were then rapidly filled with $\sim 100 \mathrm{ml}$ of inoculated water and then incubated. The sum of PPP and DPP corresponded to total primary production (TPP) and were respectively determined following a modified procedure of the one described in Garde \& Caillau (2000). After incubation, $5 \mathrm{ml}$ of total subsample were placed in a scintillation vial and acidified with $20 \mu$ l of $6 \mathrm{~N} \mathrm{HCl}$ (final $\mathrm{pH} \sim 2$ ) and slowly agitated $(\sim 150 \mathrm{rpm})$ for $\sim 6 \mathrm{~h}$. Finally, at least $4 \mathrm{~h}$ before counting, $15 \mathrm{ml}$ of a liquid scintillation cocktail (Ultima Gold LLT, Perkin Elmer) were added to determine the rate of TPP. The rest of the subsample was filtered onto a Whatman GF/F filter under low pressure $(<100 \mathrm{~mm}$ $\mathrm{Hg}$ ) and rinsed with $500 \mu \mathrm{l}$ of $0.5 \mathrm{~N} \mathrm{HCl}$ to remove labeled dissolved inorganic carbon. The filter was then placed into a scintillation vial and dried at $45^{\circ} \mathrm{C}$ for $12 \mathrm{~h}$. At least $4 \mathrm{~h}$ before counting, $10 \mathrm{ml}$ of a liquid scintillation cocktail (Ultima Gold LLT, Perkin Elmer) were added to measure PPP. The filtrate was used to determine DPP following the same procedure as TPP. The problem of a possible adsorption of dissolved carbon on GF/F filter has been previously raised (Morán et al. 1999), but Renaud et al. (2005) recently demonstrated that such an artifact was not relevant in the present type of study. Scintillation vials were counted in a Packard Scintillation Counter (TriCarb 1600) and corrected for background and quenching, and results are given in $\mathrm{mg} \mathrm{C} \mathrm{m} \mathrm{m}^{-3} \mathrm{~h}^{-1}$.

The inhibition/stimulation rates $(\Psi)$ of PPP were defined assuming that subsamples exposed to PAR were not inhibited. A decrease (inhibition) or an increase (stimulation) in the rate measured in the FS and PAR + UV-A were then associated with an effect of UV-R (Eq. 1) and UV-A (Eq. 2), respectively. The UV-B effect was deduced from the variation in FS compared to PAR + UV-A (Eq. 3). The same equations were used to calculate the $\Psi$ of DPP: 


$$
\begin{gathered}
\Psi_{\text {TOT }}(\%)=\left[1-\left(\frac{P_{\mathrm{FS}}}{\mathrm{PP}_{\mathrm{PAR}}}\right)\right] \times 100 \\
\Psi_{\mathrm{UV}-\mathrm{A}}(\%)=\left[1-\left(\frac{\mathrm{PP}_{\mathrm{PAR}+\mathrm{UV}-\mathrm{A}}}{\mathrm{PP}_{\mathrm{PAR}}}\right)\right] \times 100 \\
\Psi_{\mathrm{UV}-\mathrm{B}}(\%)=\left[1-\left(\frac{\mathrm{PP}_{\mathrm{FS}}}{\mathrm{PP}_{\mathrm{PAR}+\mathrm{UV}-\mathrm{A}}}\right)\right] \times 100
\end{gathered}
$$

BP. BP was estimated from the rates of DNA synthesis as measured by the incorporation of $\left({ }^{3} \mathrm{H}\right.$-methyl) thymidine $\left({ }^{3} \mathrm{HTdR}\right)$ using the microcentrifuge method (Smith \& Azam 1992). A sample aliquot $(2.5 \mathrm{ml})$ was added to a sterile polystyrene snap cap tube containing a saturating concentration of $10 \mathrm{nM}{ }^{3} \mathrm{HTdR}$ (specific activity $84.4 \mathrm{Ci} \mathrm{mmol}^{-1}$ or $3.12 \mathrm{TBq} \mathrm{mmol}^{-1}$, Perkin Elmer). Triplicate live samples and a single blank were run for each assay. Killed controls were prepared by addition of $250 \mu \mathrm{l} 50 \%$ trichloroacetic acid (TCA) 15 min before the addition of ${ }^{3} \mathrm{HTdR}$. BP was measured in the dark at in situ temperature using a short incubation time (no longer than $1 \mathrm{~h}$ ) to minimize repair of UV damage by bacteria (Kaiser \& Herndl 1997). Incorporation was terminated by transferring replicate $1 \mathrm{ml}$ samples from each tube into microcentrifuge tubes containing $100 \mu \mathrm{l} 50 \%$ TCA. Samples were stored for a least $2 \mathrm{~h}$ at $4^{\circ} \mathrm{C}$ and then centrifuged for $12000 \times g$ for $15 \mathrm{~min}$. The precipitates were rinsed twice with $5 \%$ TCA, once with $70 \%$ ethanol and were resuspended in $0.5 \mathrm{ml}$ of liquid scintillation cocktail (Ultima Gold LLT, Perkin Elmer) prior to radioactivity determination by liquid scintillation counter (TriCarb 1600, Packard). ${ }^{3} \mathrm{HTdR}$ incorporation rates were converted into carbon production using the conversion factor of $2.91 \times 10^{18} \mathrm{cells} \mathrm{mol}^{-1}$ of ${ }^{3} \mathrm{HTdR}$ incorporated (Briand et al. 2004) and using a cell-tocarbon conversion factor of $12.4 \mathrm{fg} \mathrm{cell}^{-1}$ (Fukuda et al. 1998). When significant differences $(p<0.05)$ were observed among light treatments, $\Psi$ of BP due to light (Eq. 4), PAR (Eq. 5), UV-A (Eq. 6) and UV-B (Eq. 7) were calculated as follows:

$$
\begin{gathered}
\Psi_{\mathrm{TOT}}(\%)=\left[1-\left(\frac{\mathrm{B} P_{\mathrm{FS}}}{\mathrm{BP}_{\mathrm{DK}}}\right)\right] \times 100 \\
\Psi_{\mathrm{PAR}}(\%)=\left[1-\left(\frac{\mathrm{B} P_{\mathrm{PAR}}}{\mathrm{B} P_{\mathrm{DK}}}\right)\right] \times 100 \\
\Psi_{\mathrm{UV}-\mathrm{A}}(\%)=\left[1-\left(\frac{\mathrm{B} P_{\mathrm{PAR}+\mathrm{UV}-\mathrm{A}}}{\mathrm{B} P_{\mathrm{PAR}}}\right)\right] \times 100 \\
\Psi_{\mathrm{UV}-\mathrm{B}}(\%)=\left[1-\left(\frac{\mathrm{BP} P_{\mathrm{FS}}}{\mathrm{BP}_{\mathrm{PAR}+\mathrm{UV}-\mathrm{A}}}\right)\right] \times 100
\end{gathered}
$$

Statistical analysis. Integrated values (i.e. aerial production) were calculated by trapezoidal method. The differences in PP and BP among the various light treatments were assessed with the Mann-Whitney $U$-test. All significant results are reported at the 0.05 level.

\section{RESULTS}

\section{Hydrology, nutrients and DOM}

At each station, the water column was homogeneous and there was no gradient in temperature and salinity, as identified on a temperature vs. salinity plot (Fig. 3). Thus, the stations were clearly separated along a weak thermal (from 23.9 to $24.7^{\circ} \mathrm{C}$ ) and salinity (from 35.7 to 36.2 ) gradient from Stn M51, near the coral barrier, characterized by the lowest values, to Stn M33b, characterized by intermediate values, and to the coastal Stn N12, characterized by the highest values (see Table 1, Fig. 3). During the study period, nutrient concentrations $\left(\mathrm{NO}_{3}+\mathrm{NO}_{2}\right.$, $\mathrm{NH}_{4}$ and $\mathrm{PO}_{4}$ ) were particularly low and generally close to detection limit (Table 1). We did not observe any significant gradient of inorganic macronutrients along the transect, except for $\mathrm{Si}(\mathrm{OH})_{4}$ which was higher at the coastal Stn N12 $\left(3.5 \mu \mathrm{mol} \mathrm{l}^{-1}\right)$ and minimum at Stn M51 $\left(1.5 \mu \mathrm{mol} \mathrm{l}^{-1}\right)$. Overall, nutrient-poor water with a low $(<2.6)$ DIN:DIP ratio was found along the whole transect (Table 1). This observation suggested a N- and P-co-limitation for the pelagic community.

In contrast to nutrients, a clear gradient was present in terms of DOM during the cruises (Table 1), similar to that of $\mathrm{Si}(\mathrm{OH})_{4}$. Indeed, DOC and CDOM absorption were low (63.7 $\mathrm{mol} \mathrm{l}^{-1}$ and $0.12 \mathrm{~m}^{-1}$, respectively) and characteristic of oligotrophic conditions at Stn M51 and then sharply increased towards the coastal Stn N12 (by a factor 1.5 and 3 for DOC and CDOM, respectively).

\section{Irradiance and underwater solar radiation}

Surface ambient daily doses ranged from ca. 6700 to $8700 \mathrm{~kJ} \mathrm{~m}^{-2}$ for PAR, 1500 to $2000 \mathrm{~kJ} \mathrm{~m}^{-2}$ for UV-A, and 23 to $30 \mathrm{~kJ} \mathrm{~m}^{-2}$ for UV-B, whereas similar maximal midday irradiance and clear skies were observed for the 3 measurement days. Spectral composition of surface irradiance was similar throughout the experiment ( $81 \%$ of PAR, $18 \%$ of UV-A and $0.3 \%$ of UV-B), and 75 to $90 \%$ of the daily total dose was received by the samples during the incubation (Table 1).

According to the Jerlov system of marine waters optical classification, the spectral variation of the light extinction coefficient $\left(k_{d}\right)$ measured in water from Stn M51 (i.e. with the highest transparency) was like that of oceanic water type OI (Fig. 4a). The $k_{d}$ variation from Stn M33b approached that of oceanic water type 
Table 1. Station and sample characteristics. Midday irradiances are given as a proxy for maximum irradiance. $I_{\text {tot }}=$ daily irradiance dose, $I_{\mathrm{d}}$ incubation = percentage of $I_{\text {tot }}$ received by incubated samples, $Z_{10 \%}=$ theoretical depth reached by $10 \%$ of surface irradiance intensity, $\mathrm{PO}_{4}=$ phosphate, $\mathrm{NO}_{3+2}=$ nitrate + nitrite, $\mathrm{NH}_{4}=$ ammonia, $\mathrm{DIN}=$ dissolved inorganic nitrogen, $\mathrm{Si}(\mathrm{OH})_{4}=$ silicate, $\mathrm{DOC}=$ dissolved organic carbon, $\mathrm{CDOM}=$ colored dissolved organic matter, $\mathrm{Pi}-$ coeuk. photo $=$ phototrophic picoeukaryotes, Nanoeuk. photo. $=$ phototrophic nanoeukaryotes, $\mathrm{PPP}=$ particulate primary production for PAR sample at $4 \mathrm{~m}$ depth, IPPP = integrated PPP between 0 and $8 \mathrm{~m}$ depths for PAR samples, $\mathrm{BP}=$ rate of bacterial production before light exposure, IBP = integrated bacterial production between 0 and $8 \mathrm{~m}$ depths for dark (DK) samples

\begin{tabular}{|c|c|c|c|}
\hline & Stn M51 & Stn M33b & Stn N12 \\
\hline \multicolumn{4}{|l|}{ Station characteristics } \\
\hline Sampling date $(\mathrm{d} / \mathrm{mo} / \mathrm{yr})$ & $26 / 11 / 2004$ & 02/12/2004 & $29 / 11 / 2004$ \\
\hline Latitude $\left({ }^{\circ} \mathrm{S}\right)$ & $22^{\circ} 21.58^{\prime}$ & $22^{\circ} 20.43^{\prime}$ & $22^{\circ} 17.40^{\prime}$ \\
\hline Longitude $\left({ }^{\circ} \mathrm{E}\right)$ & $166^{\circ} 13.36^{\prime}$ & $166^{\circ} 23.71^{\prime}$ & $166^{\circ} 27.44^{\prime}$ \\
\hline Depth (m) & 12 & 16 & 14 \\
\hline Incub. duration (h) & 6.50 & 6.75 & 6.50 \\
\hline \multicolumn{4}{|l|}{ PAR } \\
\hline Midday irradiance $\left(\mathrm{W} \mathrm{m}^{-2}\right)$ & 436.4 & 436.6 & 437.0 \\
\hline$I_{\text {tot }}\left(\mathrm{kJ} \mathrm{m}^{-2}\right)$ & 8656 & 6670 & 8316 \\
\hline$I_{\mathrm{d}}$ incubation (\%) & 77 & 83 & 75 \\
\hline$Z_{10 \%}(\mathrm{~m})$ & 21 & 10 & 8 \\
\hline \multicolumn{4}{|l|}{ UV-A } \\
\hline$I_{\text {tot }}\left(\mathrm{kJ} \mathrm{m}^{-2}\right)$ & 1953 & 1523 & 1877 \\
\hline$I_{\mathrm{d}}$ incubation $(\%)$ & 77 & 85 & 76 \\
\hline$Z_{10 \%}(\mathrm{~m})$ & 16 & 8 & 4 \\
\hline \multicolumn{4}{|l|}{ UV-B } \\
\hline$I_{\text {tot }}\left(\mathrm{kJ} \mathrm{m}^{-2}\right)$ & 29.4 & 22.6 & 28.5 \\
\hline$I_{\mathrm{d}}$ incubation (\%) & 86 & 90 & 85 \\
\hline$Z_{10 \%}(\mathrm{~m})$ & 12 & 5 & 3 \\
\hline \multicolumn{4}{|l|}{ Sample (5 m) characteristics } \\
\hline Temperature $\left({ }^{\circ} \mathrm{C}\right)$ & 24.0 & 24.3 & 24.7 \\
\hline Salinity & 35.70 & 36.01 & 36.16 \\
\hline \multicolumn{4}{|l|}{ Nutrients } \\
\hline $\mathrm{PO}_{4}\left(\mu \mathrm{mol} \mathrm{l} l^{-1}\right)$ & 0.02 & 0.01 & 0.03 \\
\hline $\mathrm{NO}_{3+2}\left(\mu \mathrm{mol} \mathrm{l} \mathrm{l}^{-1}\right)$ & 0 & 0 & 0 \\
\hline $\mathrm{NH}_{4}\left(\mu \mathrm{mol} \mathrm{l} \mathrm{l}^{-1}\right)$ & 0.01 & 0.01 & 0.01 \\
\hline $\mathrm{DIN}: \mathrm{PO}_{4} \mathrm{P}$ & 1.0 & 2.6 & 1.0 \\
\hline $\mathrm{Si}(\mathrm{OH})_{4}\left(\mu \mathrm{mol} \mathrm{l}{ }^{-1}\right)$ & 1.5 & 2.6 & 3.5 \\
\hline \multicolumn{4}{|l|}{ DOM } \\
\hline DOC $\left(\mu \mathrm{mol} \mathrm{l} \mathrm{l}^{-1}\right)$ & 63.7 & 76.2 & 96.3 \\
\hline $\operatorname{CDOM}\left(\mathrm{a}_{(350)} \mathrm{m}^{-1}\right)$ & 0.12 & 0.22 & 0.34 \\
\hline \multicolumn{4}{|l|}{ Biomass } \\
\hline Chl a $\left(\mathrm{mg} \mathrm{m}^{-3}\right)$ & 0.1 & 0.3 & 3.7 \\
\hline Phaeopigment $\left(\mathrm{mg} \mathrm{m}^{-3}\right)$ & 0.06 & 0.06 & 0.71 \\
\hline Bacteria $\left(10^{5}\right.$ cells $\left.\mathrm{ml}^{-1}\right)$ & 4.1 & 8.8 & 7.9 \\
\hline Synechococcus $\left(10^{3}\right.$ cells ml $\left.{ }^{-1}\right)$ & 1.9 & 7.3 & 11.3 \\
\hline Picoeuk. photo. $\left(10^{3}\right.$ cells $\left.\mathrm{ml}^{-1}\right)$ & 0.6 & 6.9 & 9.5 \\
\hline Nanoeuk. photo. $\left(10^{2}\right.$ cells $\left.\mathrm{ml}^{-1}\right)$ & 0.3 & 3.4 & 11.1 \\
\hline \multicolumn{4}{|l|}{ Production } \\
\hline IPPP (PAR ; 0-8 m) $\left(\mathrm{mg} \mathrm{C} \mathrm{m}^{-2} \mathrm{~h}^{-1}\right)$ & 4.7 & 34.1 & 142 \\
\hline PPP (PAR) (mg C m $\left.{ }^{-3} \mathrm{~h}^{-1}\right)$ & 0.52 & 4.45 & 18.99 \\
\hline IBP $\left(\mathrm{DK}_{;} 0-8 \mathrm{~m}\right)\left(\mathrm{mg} \mathrm{C} \mathrm{m}{ }^{-2} \mathrm{~h}^{-1}\right)$ & 0.6 & 4.2 & 19 \\
\hline BP (before expo.) (mg C m $\left.{ }^{-3} \mathrm{~h}^{-1}\right)$ & 0.03 & 0.25 & 0.53 \\
\hline
\end{tabular}

OII (i.e. similar to values measured in the Mediterranean Sea or Antarctic Ocean according to the review of Tedetti \& Sempéré 2006). In contrast, the $k_{d}$ variation from Stn N12 was characterized by higher values all along the spectrum, especially for the UV-R region, similar to rich coastal waters between types C1 and C5 for 300 to $570 \mathrm{~nm}$ and to type C9 for higher wavelengths (Fig. 4a). Finally, although there were similar surface irradiance doses during incubations, the spectral distribution of light along the water column varied strongly among the sampled stations (Fig. 4b). For example, the isoline $100 \mathrm{~mW} \mathrm{~m}^{-2}$ $\mathrm{nm}^{-1}$ for the UV-R spectral region reached $6 \mathrm{~m}$ at the most coastal Stn $\mathrm{N} 12$, deepened to ca. $10 \mathrm{~m}$ for Stn M33b but exceeded $15 \mathrm{~m}$ at the oligotrophic Stn M51. Indeed, the depth for $10 \%$ of the surface irradiance varied 3 - to 4 -fold along the gradient for the 3 considered spectral regions (Table 1).

DNA effective radiation was rapidly attenuated in the water column for Stn N12 and at lower but similar rates for Stns M33b and M51. With the exception of Stn M51, no DNA damage was measured at $8 \mathrm{~m}$ depth. The lower quantity of CPD measured at the surface of Stn M33b could be related to the lower incident UV-B radiation dose measured during the deployment of the moored system at this station (see Table 1). Indeed, the depth of $Z_{10 \%}$ DNA was in good agreement with the depth of $Z_{10 \%}$ UV-B (Fig. 5). However this relation needs to be further investigated.

\section{Distribution of biomass index}

A distribution pattern similar to that described above for DOM was observed for chlorophyll concentration, which is an index of autotrophic biomass. The autotrophic biomass was 10 times higher at the coastal Stn N12 $\left(3.7 \mathrm{mg} \mathrm{m}^{-3}\right.$ ) than at Stn M33b, which was already 3 times higher than at Stn M51. Thus, there was a clear increase in chlorophyll concentration along the transect associated with modifications in community structure (Table 1). This was illustrated by an increase in the proportion of large nanoeukaryotes compared to 


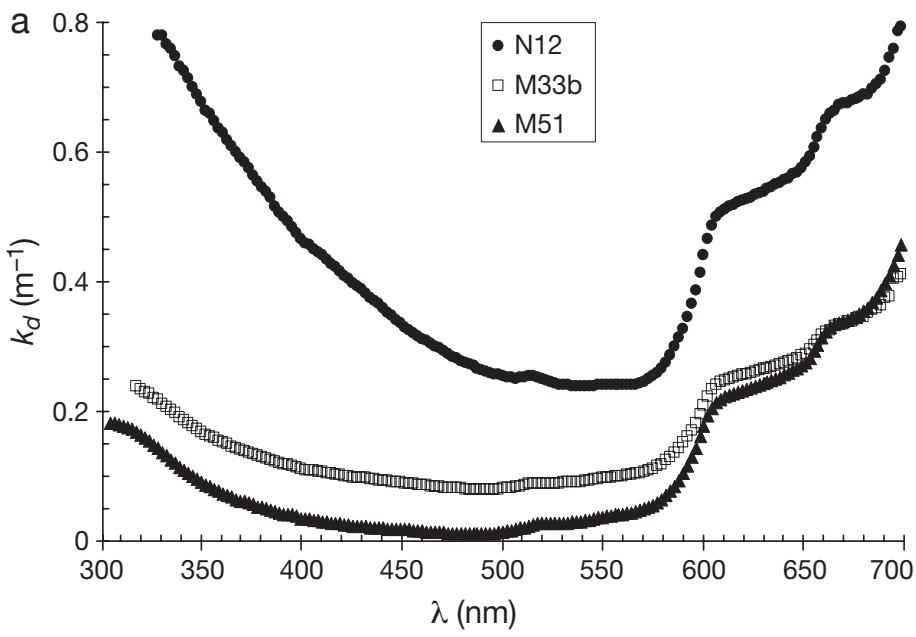

Fig. 4. (a) Variation of the light extinction coefficient $k_{d}$ with wavelength $(\lambda)$ for the 3 sampled stations. (b) Trend of light spectrum intensity (in $\mathrm{mW} \mathrm{m} \mathrm{m}^{-2} \mathrm{~nm}^{-1}$ ) along the water column for the 3 sampled stations. Daily irradiance dose $\left(I_{\mathrm{UV}-\mathrm{B}}+I_{\mathrm{UV}-\mathrm{A}}+I_{\mathrm{PAR}}\right)$ is given on the right in $\mathrm{kJ} \mathrm{m}^{-2}$. The limits of UV-B, UV-A and PAR are shown by the vertical lines

Synechococcus and picoeukaryote cells towards the coastal area. Indeed, the former represented less than $1 \%$ of the flow cytometric counts at the oligotrophic Stn M51, but ca. $5 \%$ at the coastal Stn N12. In addition, the proportion of Synechococcus changed from $75 \%$ at Stn M51 to ca. 50\% at Stns M33b and N12.

Bacterial abundance varied significantly among the stations, but not in relation to the gradient described previously (Table 1). Indeed, maximum bacterial cell abundance was observed at the intermediate Stn M33b $\left(8.8 \times 10^{5}\right.$ cells $\left.\mathrm{ml}^{-1}\right)$, whereas the minimum value was encountered at the oligotrophic Stn M51 $\left(4.1 \times 10^{5}\right.$ cells ml $\left.^{-1}\right)$. At Stn N12, bacterial abundance was $7.9 \times 10^{5}$ cells ml ${ }^{-1}$.

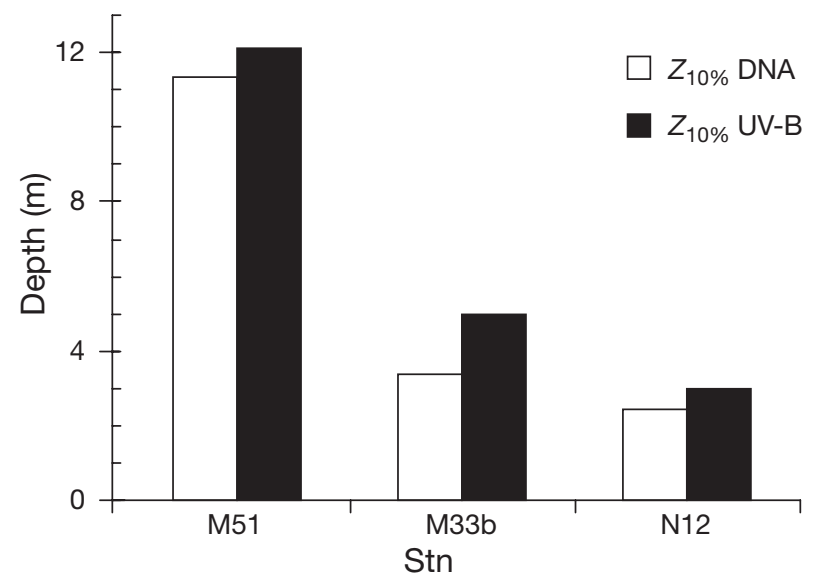

Fig. 5. Depth of $Z_{10 \%}$ DNA and of $Z_{10 \%}$ UV-B for the 3 sampled stations

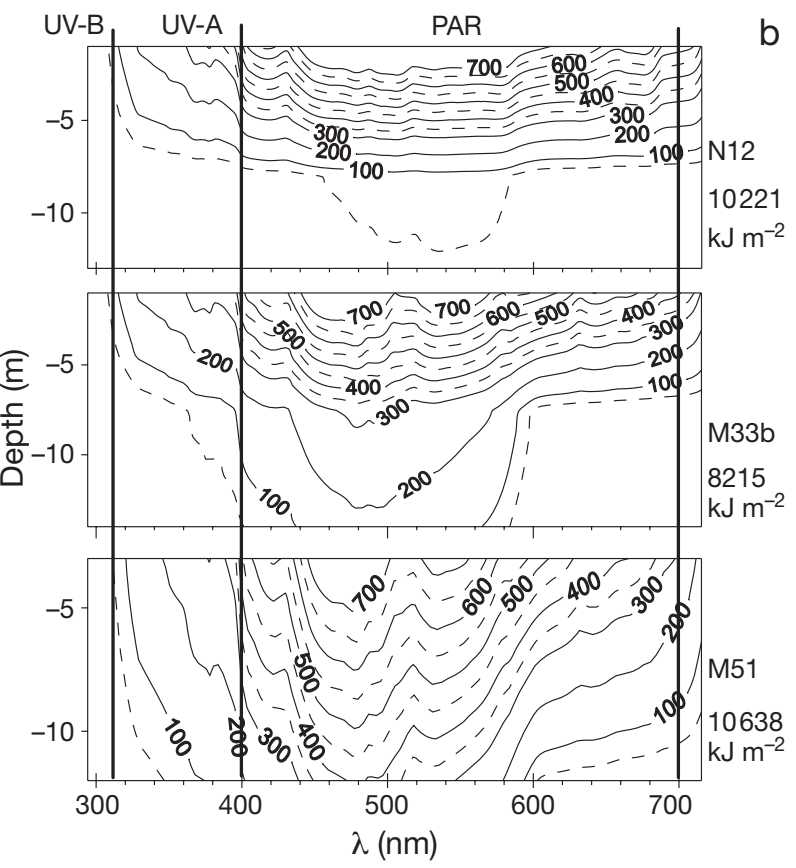

PPP (of PAR samples) and BP (before exposure)

PPP and BP reached maximum values at the coastal Stn N12 (24.28 \pm 0.97 and $0.53 \pm 0.01 \mathrm{mg} \mathrm{C} \mathrm{m}^{-3} \mathrm{~h}^{-1}$, respectively) and then gradually decreased towards the offshore station (Fig. 6a,c). Minimum values were measured at Stn M51 $\left(0.68 \pm 0.08 \mathrm{mg} \mathrm{C} \mathrm{m}^{-3} \mathrm{~h}^{-1}\right.$ for PPP and $0.03 \pm 0.01 \mathrm{mg} \mathrm{C} \mathrm{m}^{-3} \mathrm{~h}^{-1}$ for BP). On a volumetric basis (keeping in mind that each sample was divided into 3 subsamples that were incubated at 3 different depths), BP showed a similar vertical pattern at all stations, with lowest values at the surface and then a slight increase with depth (Fig. 6c). Vertical distribution was quite different for PPP, which was characterized by relatively homogeneous values along the water column for Stns M33b and M51 and by a decrease from the surface to $8 \mathrm{~m}$ depth for Stn N12 (Fig. 6a). Note that for Stn M51, PPP in samples submitted to other light treatments tended to increase with depth.

On an aereal basis, integrated PPP (IPPP) and integrated BP (IBP) decreased ca. 4-fold between Stns N12 and M33b and then 7 -fold from Stn M33b to Stn M51 (Table 1). Thus, on an hourly basis, IBP represented ca. 12 to $13 \%$ of the IPPP at the various stations (Table 1), i.e. ca. 21 to $23 \%$ on a daily basis. Note that this percentage should be considered with care because of the conversion factors used for BP. Moreover, when considering all data (not only PPP in PAR and BP before exposure), there was a significant linear relationship between PPP and BP at Stn M51 $\left(\mathrm{r}^{2}=0.81 ; \mathrm{p}<0.001 ; \mathrm{n}=9\right)$ and for pooled data from Stns M51 and M33b $\left(r^{2}=0.93\right.$; $\mathrm{p}<10^{-5} ; \mathrm{n}=18$ ). In contrast, no significant linear rela- 
Stn $\mathbf{N 1 2}$

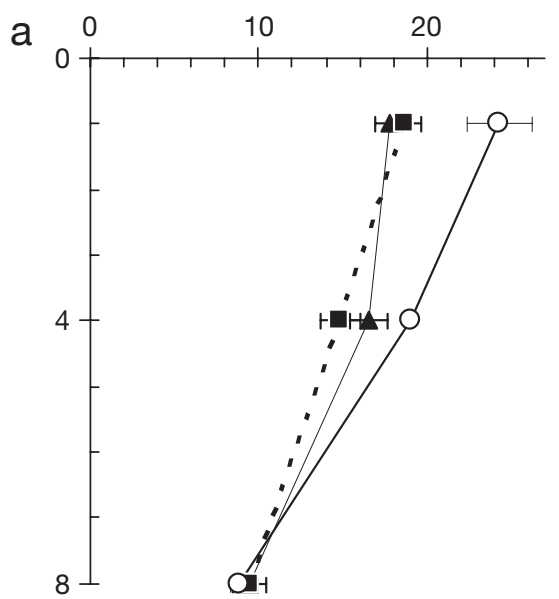

Stn M33b

$\operatorname{PPP}\left(\mathrm{mg} \mathrm{C} \mathrm{m}^{-3} \mathrm{~h}^{-1}\right)$

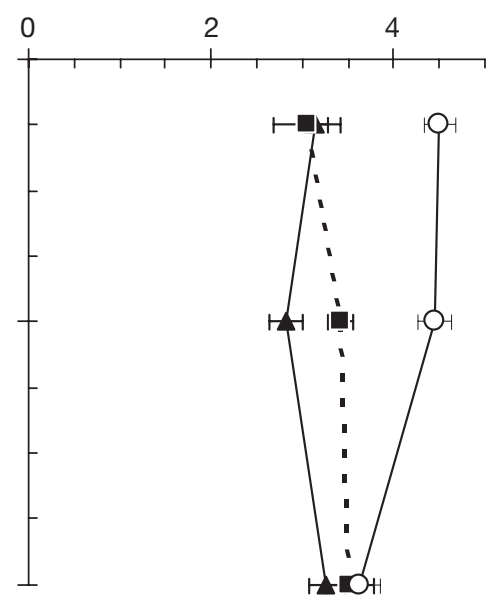

$\operatorname{DPP}\left(\mathrm{mg} \mathrm{C} \mathrm{m}^{-3} \mathrm{~h}^{-1}\right)$
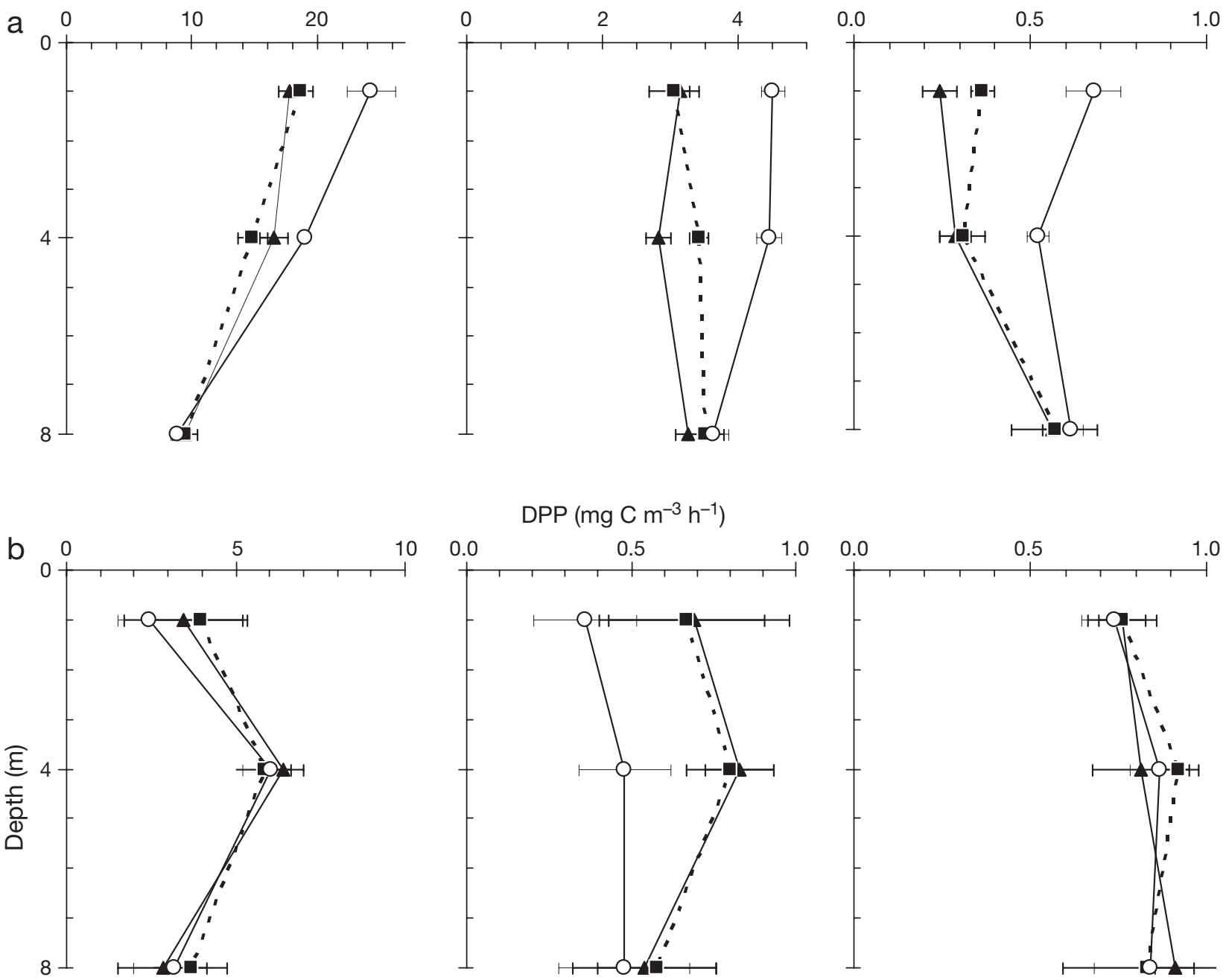

P $\left(m g \mathrm{C} \mathrm{m}^{-3} \mathrm{~h}^{-1}\right)$
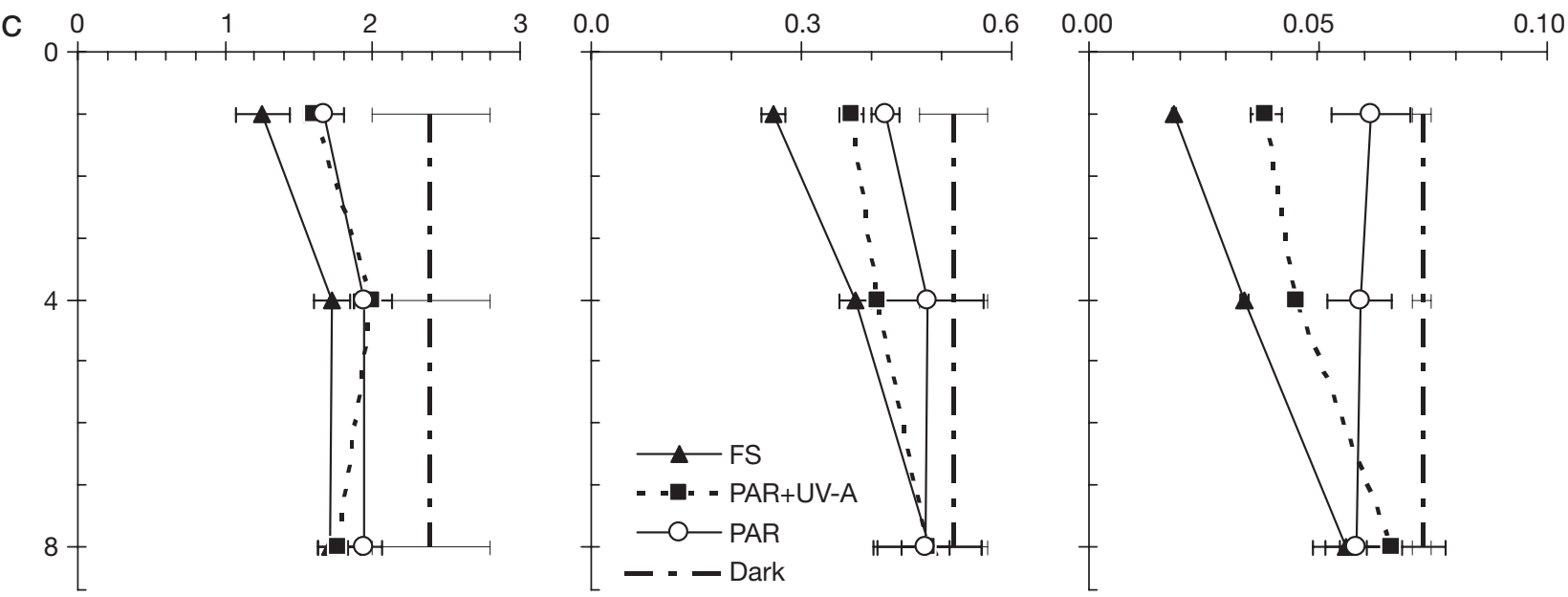

Fig. 6. Vertical distribution for each station of (a) particulate primary production (PPP), (b) dissolved primary production (DPP) and (c) bacterial production (BP) 
tionship coould be defined for data from Stn N12 or from the pooled whole set (Fig. 7).

The spatial variation of PPP was mainly related to the variation of biomass, as illustrated by the relative constancy of the rate of PP normalized to chlorophyll concentration (i.e. the ratio between $\mathrm{PPP}$ and $\mathrm{PP}^{\mathrm{chl}}$ ) along the gradient (previously named PE for phytoplankton efficiency in Conan et al. 1999). Between 0 and $8 \mathrm{~m}$, the $\mathrm{PP}^{\mathrm{chl}}$ of the PAR samples were $4.7 \pm 2.1 \mathrm{mg} \mathrm{C}$ $(\mathrm{mg} \mathrm{chl})^{-1} \mathrm{~h}^{-1}$ for Stn N12, $6.4 \pm 0.7 \mathrm{mg} \mathrm{C}(\mathrm{mg} \mathrm{chl})^{-1} \mathrm{~h}^{-1}$ for Stn M33b and $4.5 \pm 0.6 \mathrm{mg} \mathrm{C}(\mathrm{mg} \mathrm{chl})^{-1} \mathrm{~h}^{-1}$ for Stn M51. Contrary to the values obtained for $\mathrm{PP}^{\mathrm{chl}}$, we observed a large spatial variation in DPP, with highest rates measured at Stn N12 (10 times higher than for the other stations). Vertical distribution of DPP was almost constant for the 3 sampled stations, with a maximum at $4 \mathrm{~m}$ (Fig. 6b). In order to compare the effect of spectral composition of solar radiation on organic carbon release among experiments with different phytoplankton assemblages, DPP was normalized to the respective TPP $(\% \mathrm{DPP}=\mathrm{DPP} /[\mathrm{PPP}+\mathrm{DPP}])$. Indeed, this $\% \mathrm{DPP}$, which directly fuels the dissolved organic compartment, was minimal for the intermediate Stn M33b $(10 \pm 2 \%)$, double for the richer Stn N12 (20 $\pm 9 \%)$ and reached $57 \pm 5 \%$ for the oligotrophic Stn M51.

\section{UV-R effects on PPP and DPP}

Phytoplankton carbon fixation rates increased when ambient UV-R was excluded (PAR samples) compared to unfiltered samples (FS) at $1 \mathrm{~m}$ depth for all sampled stations (Fig. 6a). With the exception of Stn N12, the same observation was made at $4 \mathrm{~m}$. Finally, no signifi-

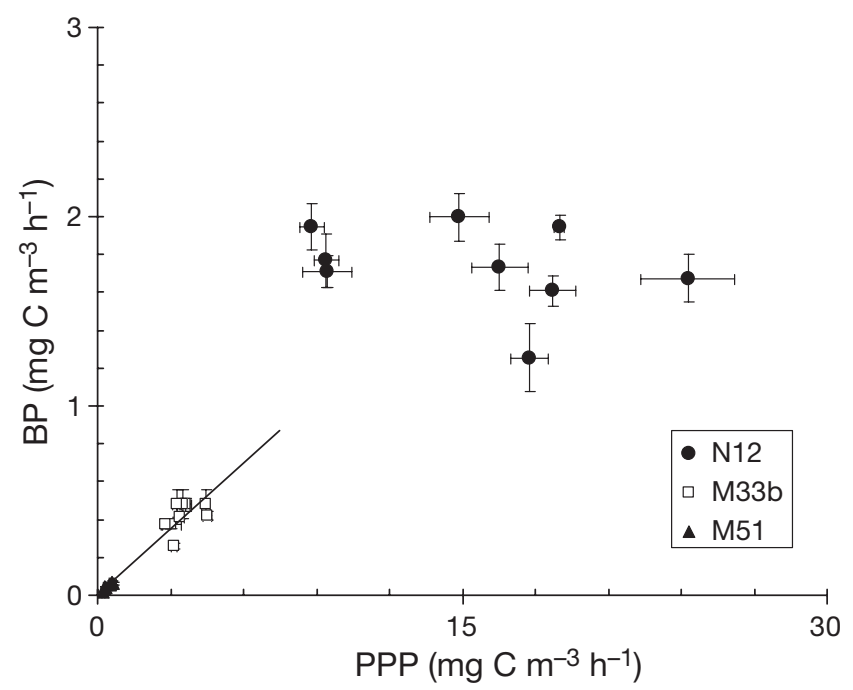

Fig. 7. Relationship between particulate primary production (PPP) and bacterial production (BP). Linear relationship is given for pooled data from Stns M33b and M51 $(B P=0.116 \times$ $\left.\mathrm{PPP}+0.001 ; \mathrm{r}^{2}=0.93 ; \mathrm{n}=18 ; \mathrm{p}<0.00001\right)$ cant difference was observed between the various light treatments at $8 \mathrm{~m}$. A superimposed effect of UV-B to UV-A (PAR + UV-A samples) on the incorporation of ${ }^{14} \mathrm{C}$ by phytoplankton was observed at $1 \mathrm{~m}$ depth for Stn M51. Indeed, at $1 \mathrm{~m}, \mathrm{PPP}$ was $0.68 \pm 0.08 \mathrm{mg} \mathrm{C} \mathrm{m}^{-3}$ $\mathrm{h}^{-1}$ under the PAR treatment, $0.36 \pm 0.03 \mathrm{mg} \mathrm{C} \mathrm{m}^{-3} \mathrm{~h}^{-1}$ under the PAR + UV-A treatment but $0.24 \pm 0.05 \mathrm{mg} \mathrm{C}$ $\mathrm{m}^{-3} \mathrm{~h}^{-1}$ under the FS treatment, whereas at the coastal Stn N12, PPP values decreased from $24.3 \pm 1.9 \mathrm{mg} \mathrm{C}$ $\mathrm{m}^{-3} \mathrm{~h}^{-1}$ under the PAR treatment to $19.2 \pm 2.0 \mathrm{mg} \mathrm{C}$ $\mathrm{m}^{-3} \mathrm{~h}^{-1}$ under the PAR + UV-A treatment and $17.8 \pm$ $0.8 \mathrm{mg} \mathrm{C} \mathrm{m}^{-3} \mathrm{~h}^{-1}$ under the FS treatment (Fig. 6a). Overall, UV-A significantly ( $\mathrm{p}<0.05$ ) inhibited PPP by 16 to $28 \%$ at Stn N12, by 24 to $33 \%$ at Stn M33b and by 35 to $43 \%$ at Stn M51; another $20 \%$ was due to UV-B radiation at $1 \mathrm{~m}$ for Stn M51 (Table 2).

The DPP rate was relatively constant along the water column (Fig. 6b). We found no significant difference among the various light treatments for DPP values at Stns N12 and M51 (Table 2). However, at Stn M33b, UVA significantly increased the DPP rates at upper (92 \pm $10 \%)$ and intermediate $(72 \pm 14 \%)$ depths. Finally, no additional effect could be attributed to UV-B, regardless of UV-A treatment which exerted the main effect.

\section{UV-R and PAR effects on BP}

In contrast to PPP, BP inhibition was measured in reference to the samples maintained in the darkness, considering both UV-R and PAR as possible stressors (Fig. 6c). The total inhibition due to solar radiation in the water column was comparable at Stns N12 and M33b and higher for Stn M51 (Table 2). However the contributions of PAR, UV-A and UV-B to this inhibition were different among stations. The inhibitory effect of PAR was maximal and generally homogeneous down to $8 \mathrm{~m}$ depth ( 19\%) at Stn M51 (Table 2). It reached 29 and $17 \%$ at 1 and $4 \mathrm{~m}$, respectively, at Stn N12 and $19 \%$ at $1 \mathrm{~m}$, at Stn M33b (Fig. 6c, Table 2). BP was inhibited by UV-R down to $4 \mathrm{~m}$ at Stns M51 and M33b, but only to $1 \mathrm{~m}$ at Stn N12. At Stn M51, the inhibitory effect of UV-A on BP decreased with depth from 32 to $19 \%$, while that of UV$\mathrm{B}$ remained constant (28 to $34 \%$ ). At Stn M33b, the effect of UV-B on BP inhibition decreased with depth (21 and $7 \%$ at 1 and $4 \mathrm{~m}$, respectively), whereas that of UV-A increased (9 and $20 \%$ at 1 and $4 \mathrm{~m}$, respectively). For Stn N12, BP inhibition by UV-R was mostly due to UV-B at 1 and $4 \mathrm{~m}$ (14 and 5\%, respectively). When the relative contribution of UV-B and UV-A to the total UV-R inhibition was calculated at $1 \mathrm{~m}$, a clear increase in the contribution of UV-B was observed along the gradient with 47,70 and $82 \%$ for Stns M51, M33b and N12, respectively. 
Table 2. Changes in bacterial production (BP), particulate primary production (PPP) and dissolved primary production (DPP) induced by different light treatments (see 'Materials and methods' section 'In situ incubations' for explanation). BP measured in illuminated samples (PAR, PAR + UV-A and FS) was compared to BP measured in dark sample (DK), whereas PPP and DPP measured in samples receiving UV-R (PAR + UV-A and FS) were compared to samples where UV-R was excluded (PAR). Differences in BP, PPP and DPP among the various light treatments were assessed with the Mann-Whitney $U$-test. All results are mean \pm SD reported at a 0.05 significant level (ns $=$ non significant)

\begin{tabular}{|c|c|c|c|c|c|c|c|c|c|}
\hline \multirow{2}{*}{$\begin{array}{l}\text { Depth } \\
\text { (m) }\end{array}$} & \multicolumn{3}{|c|}{$\%$ inhibition of $\mathrm{BP}$} & \multicolumn{3}{|c|}{ \% inhibition of PPP } & \multicolumn{3}{|c|}{ \% stimulation of DPP } \\
\hline & $\begin{array}{c}\text { FS } \\
\text { versus } \\
\text { DK }\end{array}$ & $\begin{array}{c}\text { PAR+UV-A } \\
\text { versus } \\
\text { DK }\end{array}$ & $\begin{array}{c}\text { PAR } \\
\text { versus } \\
\text { DK }\end{array}$ & $\begin{array}{c}\text { FS } \\
\text { versus } \\
\text { PAR }\end{array}$ & $\begin{array}{c}\text { PAR+UV-A } \\
\text { versus } \\
\text { PAR }\end{array}$ & $\begin{array}{c}\text { FS } \\
\text { versus } \\
\text { PAR+UV-A }\end{array}$ & $\begin{array}{c}\text { FS } \\
\text { versus } \\
\text { PAR }\end{array}$ & $\begin{array}{c}\text { PAR+UV-A } \\
\text { versus } \\
\text { PAR }\end{array}$ & $\begin{array}{c}\text { FS } \\
\text { versus } \\
\text { PAR+UV-A }\end{array}$ \\
\hline \multicolumn{10}{|c|}{ Stn N12 } \\
\hline 1 & $46 \pm 11$ & $32 \pm 11$ & $29 \pm 12$ & $28 \pm 5$ & $21 \pm 9$ & ns & ns & ns & ns \\
\hline 4 & $26 \pm 12$ & ns & $17 \pm 13$ & $16 \pm 3$ & $22 \pm 8$ & ns & ns & ns & ns \\
\hline 8 & ns & ns & ns & ns & ns & ns & ns & ns & ns \\
\hline \multicolumn{10}{|c|}{ Stn M33b } \\
\hline 1 & $49 \pm 5$ & $28 \pm 6$ & $19 \pm 7$ & $30 \pm 7$ & $24 \pm 4$ & ns & $92 \pm 10$ & $86 \pm 6$ & ns \\
\hline 4 & $27 \pm 7$ & $20 \pm 6$ & ns & $33 \pm 6$ & $29 \pm 5$ & ns & $72 \pm 14$ & $67 \pm 8$ & ns \\
\hline 8 & ns & ns & ns & ns & ns & ns & ns & ns & ns \\
\hline \multicolumn{10}{|c|}{ Stn M51 } \\
\hline 1 & $75 \pm 1$ & $47 \pm 4$ & $15 \pm 9$ & $55 \pm 5$ & $43 \pm 6$ & $20 \pm 3$ & ns & ns & ns \\
\hline 4 & $53 \pm 2$ & $38 \pm 2$ & $19 \pm 9$ & $40 \pm 3$ & $35 \pm 7$ & ns & ns & ns & ns \\
\hline 8 & $23 \pm 6$ & ns & $19 \pm 12$ & ns & ns & ns & ns & ns & ns \\
\hline
\end{tabular}

\section{DISCUSSION}

The present investigation provides an in situ evaluation of the respective role of UV-A and UV-B in algal and bacteria activity along a coastal-offshore transect in a tropical lagoon, characterized by a gradient of trophic conditions. The role of spectral composition of solar radiation has seldom been considered as a critical factor controlling the algal-bacterial relationship.

\section{Limitation of the study}

To our knowledge, this study is the first of its kind to consider simultaneous in situ measurements of phytoplankton and bacterial activities at a daily scale along the water column; however several caveats should be kept in mind when considering the experimental results reported herein. First, the water was collected at $5 \mathrm{~m}$ depth and then incubated at 3 different depths. This strategy could be problematic in the case of strong variations of hydrological conditions and according to light and UV-R cell history. However, in the present study, the water column of the lagoon was homogeneous (Fig. 3c) at the 3 stations (mean $\pm \mathrm{SD}$ fluorescence values over the water column were $0.40 \pm 0.05,0.77 \pm 0.13$ and $2.07 \pm$ $0.42 \mathrm{mg} \mathrm{chl} \mathrm{m}^{-3}$ for Stns M51, M33b and N12, respectively, and $0.42 \pm 0.02,0.65 \pm 0.15$ and $2.06 \pm 0.04 \mathrm{mg} \mathrm{chl}$ $\mathrm{m}^{-3}$ between 4.5 and $5.5 \mathrm{~m}$ depth for Stns M51, M33b and N12, respectively). We therefore assume that there was little or no difference in cell history among the various depths and that our sampling strategy did not introduce serious bias in the inhibition measurements.
Another potential source of error concerns the fact that a variable proportion of the decrease in production observed in the samples is associated not only with the UV-R effect, but also the near-surface inhibition of photosynthesis by an excess of PAR. Indeed, this type of inhibition is a well-recognized process unavoidably included in experimental measurements (Nielsen \& Ekelund 1995, Wängberg et al. 1998). For example, after $1 \mathrm{wk}$ of moderate UV-R flux exposure, the sensitivity of Cryptomonas sp. to UV-R strongly decreased whereas that of Thalassiosira pseudomona remained unchanged (Litchman \& Neale 2005). Secondly, bacterial uptake processes, the influence of carbon released from algae and other complex abiotic (e.g. DOM photolysis and free radicals) and biotic (e.g. competition for mineral limiting nutrients) interactions can all effect our measurements. Nevertheless, these processes are expected to be low compared to the direct effect of sunlight on biological activities, especially considering the short incubation time employed $(<7 \mathrm{~h})$.

Two different methodologies were chosen for the measurement of phytoplankton and bacterial inhibition. Indeed, contrary to PPP measurements, exposure for bacteria was not conducted in the presence of the radio-labeled substrate, but by short incubations in the dark performed at the end of exposure. We chose this procedure because inconsistent results have been reported when exposure and uptake measurements were made together (Sommaruga et al. 1997) and because very little recovery of incorporation has been shown to occur during the first hour of incubation in the dark after exposure to sunlight (Kaiser \& Herndl 1997). Thus, the inhibition of BP measured at the end 
of the afternoon can be considered as representative of the highest value, particularly since UV inhibition of $\mathrm{BP}$ is cumulative over the course of the solar day (Aas et al. 1996, Visser et al. 2002).

Lastly, short-term measurements of UV-R photoinhibition can be difficult to translate to long-term ecological effects. Indeed, photorepair, photo-adaptation, increased pigmentation and/or rapid vertical mixing make the long-term ecological representativeness of static bottle incubations questionable. Finally, one important advantage of our approach is to pool all natural antagonistic environmental effects and to produce a resultant effect allowing a valuable comparison of phytoplankton and BP on a daily timescale.

\section{Studied area and environmental conditions}

The southwest lagoon of New Caledonia is characterized by severe oligotrophic conditions near the coral barrier, whereas the studied bay is subject to terrestrial and urban inputs (Jacquet et al. 2006, Mari et al. 2007). The lagoon is characterized by a clear gradient of water mass residence times from oligotrophic to inshore enriched stations (Jouon et al. 2006). It has been previously shown that bacterioplankton abundance and production spatially vary 3to 5-fold and 36- to 114 -fold, respectively, and that bacterial and phytoplankton biomass are generally correlated (Torréton et al. 2007). During the present study, the autotrophic community shifted from abundant picoplankton cells to a dominance of nanoplankton towards the coastal area (Table 1) as previously observed in this ecosystem (Jacquet et al. 2006). Phytoplankton and bacterial activity co-varies in the most oligotrophic part of the lagoon (Fig. 7). The large scatter of BP versus PP observed in the coastal part during the present study is likely consequence of allochthonous inputs (Rochelle-Newall et al. 2008).

The change of $k_{d}$ in the spectral region of UV and short PAR wavelength is generally associated with variation in the concentration of DOM and/or phytoplanktonic biomass (Piazena et al. 2002). For example, in a study of the role of UV-R in the inhibition of PP in the Norwegian waters, Erga et al.(2005) found that $k_{d}$ and chl a were closely correlated in oceanic waters, while CDOM was the main contributor to UV-R attenuation in the fjord. Despite the lack of data in the present study for such a correlation analysis, we observed a better linear dependence between $Z_{10 \%}$ of PAR, UVA, UV-B and CDOM concentration and then, with DOC concentration, than with chlorophyll concentration (data not shown). There was a good agreement between the penetration of DNA damaging radiation (biodosimeter measurements) and the penetration of unweighted UV-B irradiance (radiometric measurements). This result supports the fact that in the present study instantaneous light profiles at solar noon may be sufficient to evaluate the penetration of DNA damage effective dose over the day. In contrast, using historical data, Tedetti \& Sempéré (2006) determined that penetration of unweighted UV-B radiation may overestimate the penetration of DNA damage effective dose by 16 to $55 \%$.

\section{Inhibition of PP and BP under UV-R}

In the present study, phytoplanktonic and bacterial standing-stock and production yielded values in the range reported for the area (Jacquet et al. 2006, Mari et al. 2007). UV-R greatly inhibited phytoplanktonic production and BP. The PPP measured in FS samples represented 45 to $85 \%$ of the PPP measured in samples where UV-R was excluded depending on stations and depths. The same comparison for BP gave a range of 25 to $80 \%$. These scales were coherent with those given in the literature (Neale et al. 2001). For example, PP was UV-A inhibited by 33 to $83 \%$ depending on depth and date in a high mountain lake (Carrillo et al. 2002). Concerning bacteria, Visser et al. (2002) showed that BP inhibition by sunlight is cumulative during surface incubation (up to $80 \%$ relative to dark sample) and detectable down to a depth of $10 \mathrm{~m}$ in tropical coastal waters. In our data set, the inhibition of phytoplankton and bacteria under UV-R increased with oligotrophy and decreased with depth. We used a linear regression between inhibition and depth in order to estimate the potential range and limit of the UV-R effect. We found that the depth of $8 \mathrm{~m}$ was the deepest limit of UV-R influence on PPP and BP (Fig. 8). We also found a similar inhibition range for phytoplankton under the influence of UV-A (Fig. 8a) and for bacteria under the influence of UV-R (Fig. 8b,c). This was 32 to $68 \%$ for the former and 34 to $79 \%$ for the latter. As no significant difference was found between linear regressions of PPP and BP, inhibition data were pooled for each station (Fig. 8d) and linear regressions became: $Z=0.23 \times I \%+7.70$ for $\mathrm{Stn}$ N12, $Z=0.16 \times I \%+7.77$ for $\operatorname{Stn}$ M33b and $Z=$ $0.11 \times I \%+8.34$ for Stn M51 $(Z=$ depth in $\mathrm{m}$ and $I \%$ = inhibition in percentage). In these regressions, the slopes were only significantly different between Stns N12 and M51. We also observed that (1) bacteria were more sensitive to UV-B than phytoplankton and (2) the effect of UV-A was stronger than that of UV-B on phytoplankton (Table 2). 

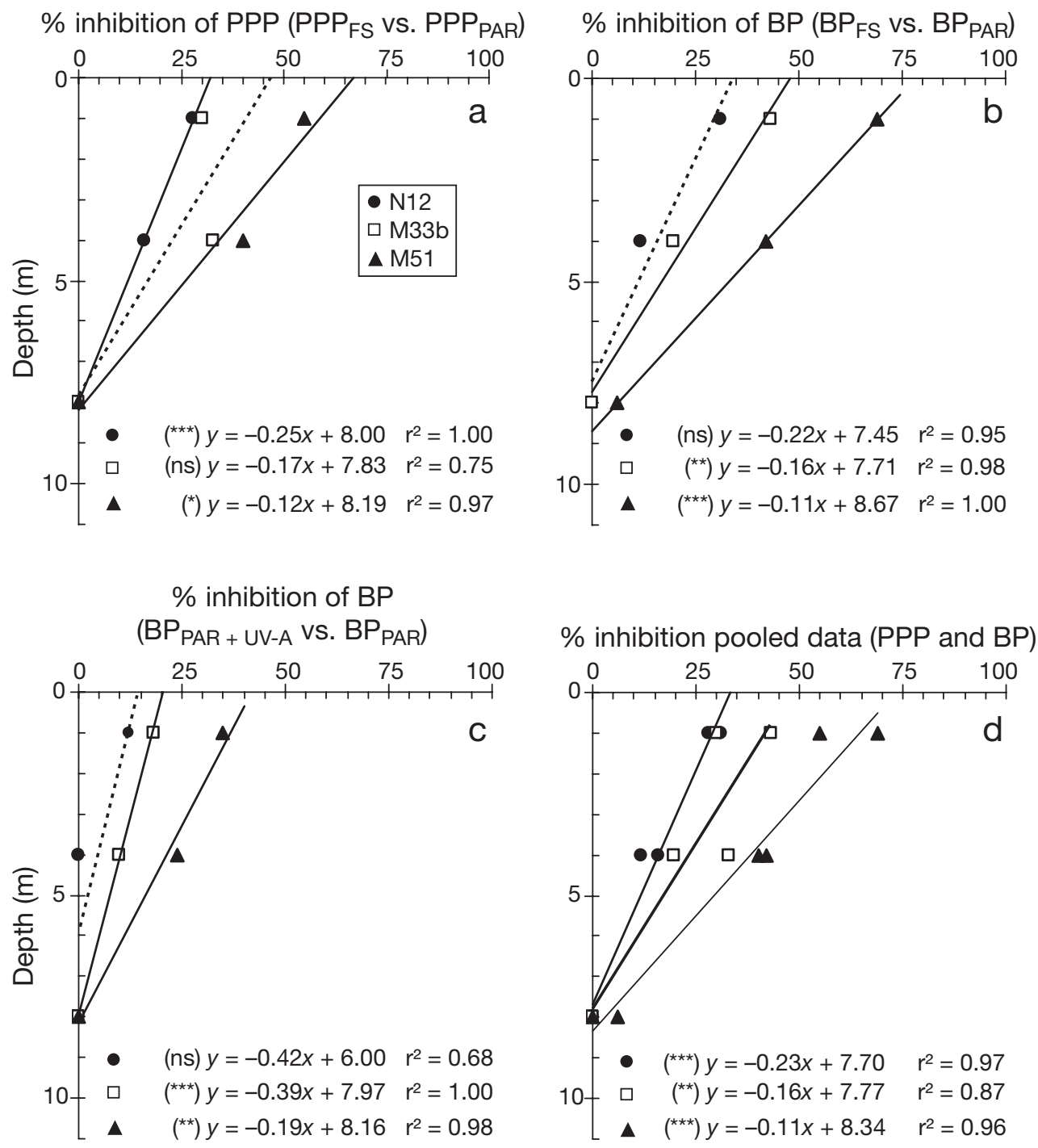

Fig. 8. Vertical distribution at the 3 stations of the percentage of inhibition of (a) particulate primary production ( $\mathrm{PPP}_{\mathrm{FS}}$ versus $\left.\mathrm{PPP}_{\mathrm{PAR}}\right)$, (b) bacterial production $\left(\mathrm{BP}_{\mathrm{FS}}\right.$ versus $\left.\mathrm{BP}_{\mathrm{PAR}}\right)$, (c) $\mathrm{BP}_{\mathrm{PAR}+\mathrm{UV}-\mathrm{A}}$ versus $\mathrm{BP}_{\mathrm{PAR}}$ and (d) pooled data of PPP and $\mathrm{BP}$. Equations of linear regressions and correlation coefficients are indicated. Solid lines are significant $\left({ }^{* * *} p<0.001,{ }^{* *} p<0.02\right.$ and

${ }^{*} \mathrm{p}<0.05$ ), contrary to dashed lines (ns: non significant, $\alpha=0.05$ )

\section{Higher sensitivity of bacteria to UV-B}

The UV-B contribution was about one-third and only at the highest inhibition of PPP (Stn M51), whereas UV-B contributed to ca. $50 \%$ in the inhibition of BP at all stations (Fig. 8). The higher sensitivity to UV-B for bacteria may be explained by the fact that DNA damage is supposed to increase with decreasing cell size (Buma et al. 2001). However, the relationship between size and sensitivity is not straightforward. For example, Karentz et al. (1991), studying 12 species of diatoms, concluded that smaller cells sustained greater amounts of damage per unit of DNA. On the other hand, Helbling et al. (2001) showed that small flagellates are strongly inhibited by UV-R, but are able to acquire resistance to UV-R by photoadaptive processes. The question is how to explain the relative weak effect of UV-B on phytoplankton, even if a clear UV-B effect is sometimes reported in natural populations of lake (Callieri et al. 2001), in marine phytoplankton (Litchman \& Neale 2005), in Norwegian coastal waters or in the southwest China Sea (Helbling et al. 2003).

Different explanations have been proposed to justify the known relative weak effect of UV-B on phytoplankton cells (Mengelt \& Prézelin 2005). The regulation of UV-B damage could be initiated through UV-A, but not UV-B, photoreceptors. In this case, phytoplankton responds to short-term changes in UV-A 
flux but is unable to respond to modification in the ratio of UV-B to UV-A for a constant dose of UV-A. That was the case in the present study, where the UVA dose was identical for FS and PAR + UV-A samples, whereas the FS sample received UV-B in addition. Alternatively, Cullen \& Neale (1994) suggested that a relatively weak UV-B effect was observed because UV-A inhibition was dominant and could hide the UV-B stress, in the same way that an excess of PAR could eventually hide the UV-A stress. To conclude, we agree with Carrillo et al. (2002) that the non-effect of UV-B is more likely due to the rapid extinction of UV-B in the water column (Fig. 4) than to a potential resistance of phytoplankton.

\section{Stronger effect of UV-A than UV-B on phytoplankton}

Even if numerous studies have focused on the effect of UV-B on marine ecosystems because of the potential increase of UV-B flux in relation with the ozone depletion (UNEP 2006), earlier studies showed that UV-A is a major cause of reduced photosynthesis rates in phytoplankton (e.g. De Mora et al. 2000, Helbling et al. 2001, Neale et al. 2001, Xenopoulos \& Schindler 2003). The predominance of UV-A effect in comparison to UV-B on the phytoplankton is widely documented in other tropical or subtropical ecosystems (Piazena et al. 2002), polar (Villafañe et al. 1995) and temperate marine ecosystems (Behrenfeld et al. 1993, Helbling et al. 2001), but also in lakes (Neale et al. 2001, Carrillo et al. 2002). In fact, a wide range of interspecific UV-R tolerance in phytoplankton has been reported (Gieskes \& Buma 1997, De Mora et al. 2000). The shape of the inhibition to the UV-R dose or dose rate has been determined as linear, sigmoidal, or hyperbolic, with or without threshold (see review of Smith \& Cullen 1995). No single response seems to explain photosynthetic and/or BP inhibition by UV-R. In the present study, the response of PPP and BP inhibition to the UV-R dose was clearly linear without apparent threshold (Fig. 9). This observation concerns the effect of UV-A on both phytoplankton and bacteria (Fig. 9a,d), but also the effect of UV-B on bacteria (Fig. 9e). Samples where the contribution of UV-B to the inhibition of PPP was significant are too scarce to define a relationship (Fig. 9b). Linear relationship without threshold suggests that propriety of reciprocity (i.e. the effect is only function of cumulative exposure independently of irradiance) holds for our experimental conditions (several hours with solar irradiance), in agreement with Behrenfeld et al. (1993). In fact, these repair processes use different parts of the solar spectrum and are likely to operate on different and longer time scales. One way of defining thresholds in the present study is to consider the relationship between inhibition of production and the ratio of UV-B:UV-A dose (Fig. 9c,f). Below these thresholds (i.e. 0.002 and 0.004 for PPP and BP, respec-
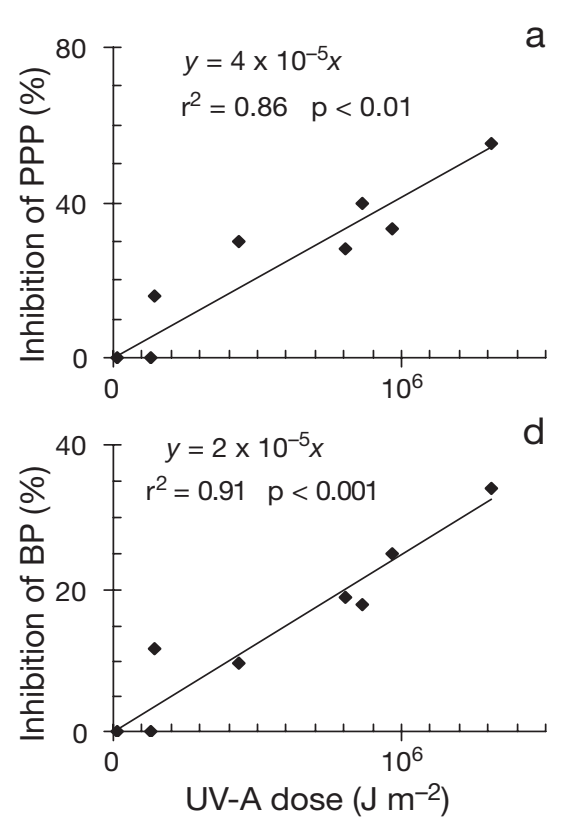
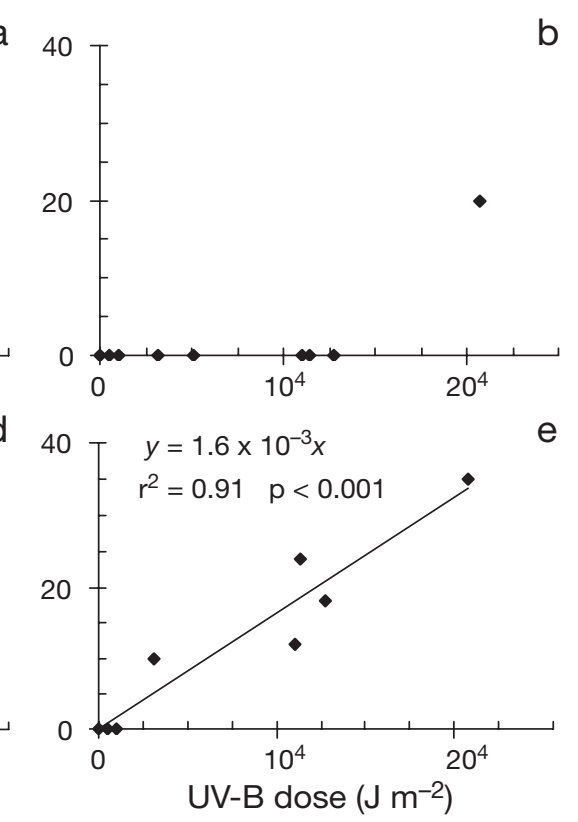

b 80

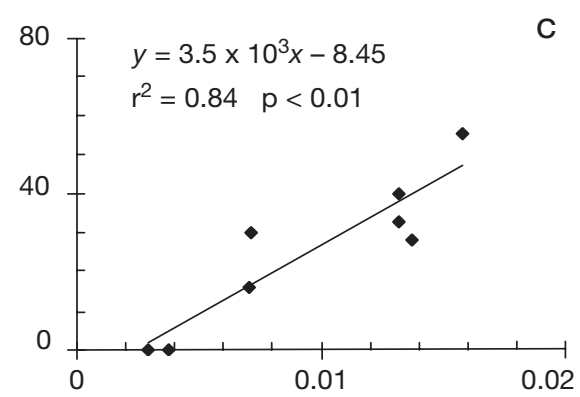

e 80

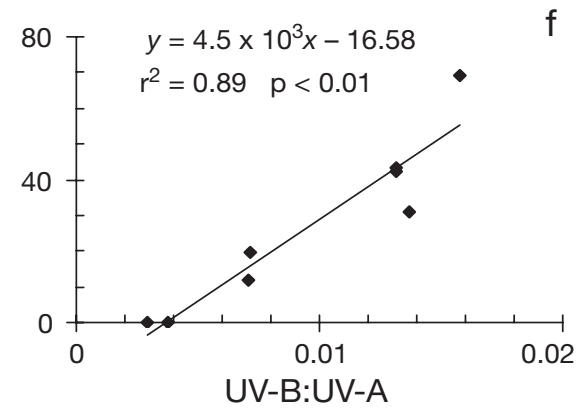

Fig. 9. Relationship between inhibition of (a) particulate primary production (PPP) by UV-A and the unweighted UV-A dose, (b) PPP by UV-B and the unweighted UV-B dose, (c) PPP by UV-R and the ratio of unweighted UV-B:UV-A dose, (d) bacterial production (BP) by UV-A and the unweighted UV-A dose, (e) BP by UV-B and the unweighted UV-B dose and (f) inhibition of BP by UV-R and the ratio of unweighted UV-B:UV-A dose. Linear regression equations, correlation coefficients and probabilities are indicated when significant 
tively), respective production was not depressed by UV-R, whereas above them, the inhibitions increased linearly.

\section{Effect of UV-R on carbon release by phytoplankton}

Bacteria are able to take up fresh carbon in the dark with greater efficiency than under full sunlight (Carrillo et al. 2002). This could be related to UV-R inhibition of bacterial growth or to a decrease of bioavailability of carbon released by phytoplankton due to photo-transformation processes. Indeed, it is frequently proposed that UV-R induces an increase in carbon release by phytoplankton. Aas et al. (1996) reported a significant stimulatory effect of PAR and PAR + UV-A on BP associated with an increase in organic carbon release in coastal surface water of the Atlantic Barrier Coral Reef. In the same way, their bioassay experiments showed a significant increase in rates of bacterial secondary production, in the growth rates and cell volumes of bacteria grown in sunlightirradiated water samples (i.e. previously exposed to in situ ambient solar radiation). The authors suggested that exposure of natural waters to solar radiation resulted not only in inhibition of bacterial synthesis, but also in their enrichment in labile by-products of DOM that consequently enhanced overall bacterial metabolism during nighttime, after their recovery from UV stress. Finally, the effect of sunlight on the bioavailability of released material is unclear as sometimes it is higher while at other times it is reduced (Obernosterer et al. 2001).

Another important question, on which estimates disagree, concerns the proportion of PP lost under the influence of UV-R. In the present study, we did not observe a significant effect of UV-R on phytoplankton excretion, the only exception being at the intermediate Stn M33b (Table 2). The fact that UV-B does not significantly influence DPP has been previously observed in culture (Garde \& Cailliau 2000). The UV-R could increase the DPP, but not proportionally to total dose. At Stn M51, the fraction of DPP represents ca. $65 \%$ of the TPP in samples where UV-R was excluded. This high percentage indicates that phytoplankton cells are already stressed by factors other than UV-R (e.g. excess of PAR and nutrient limitations), and we can hypothesize that more stress does not significantly increase the quantity of material lost by the cells. Concerning the other 2 stations, the situation was quite different because DPP represented $<20 \%$ of the total production, and then a stimulation of the excretion is observed for the highest dose of UV-R, i.e. which was received during the experiment at Stn $\mathrm{M} 33 \mathrm{~b}$. The $\mathrm{PP}^{\mathrm{chl}}$ value is a good indicator of the proportion of material which could directly fuel the bacterial compartment (Conan et al. 1999). This previous work showed an inverse power relationship between the $\mathrm{PP}^{\mathrm{chl}}$ value and the potential for excretion. The $\mathrm{PP}^{\mathrm{chl}}$ value was maximal for Stn M33b ( 10 mg C (mg chl $\left.)^{-1} \mathrm{~h}^{-1}\right)$ and then decreased for Stns N12 and M51 ( 7 and <5 mg C $(\mathrm{mg} \mathrm{chl})^{-1} \mathrm{~h}^{-1}$, respectively) in agreement with the observed distribution of DPP. Therefore, the $\mathrm{PP}^{\mathrm{chl}}$ can be considered as a physiological stress indicator that may reflect the sensitivity to a potential UV-R stress.

This conclusion is particularly relevant when considering the significant linear relationship between the inhibition of PPP and the $\mathrm{PP}^{\mathrm{chl}}$ ratio (Fig. 10), with $\mathrm{PP}^{\mathrm{chl}}$ estimated before UV-R exposure or for samples where UV-R are excluded. It is obvious that UV-R irradiance dose is a key factor in the control of the inhibition rate of production, but this relation represents a simple way to evaluate a potential decrease in PPP under natural environmental conditions, without taking into account the dose received. In considering that highest inhibition is generally observed in surface samples, we pooled all the relevant data found in the literature and from the 3 stations of the present study to define a preliminary equation $\left(y=-3.1 x+56.9 ; r^{2}=0.65 ; n=28\right.$; $\mathrm{p}<0.001)$, indicating that when phytoplankton cells are stressed (low $\mathrm{PP}^{\mathrm{chl}}$ ) a PPP inhibition of ca. $60 \%$ and no significant increase in DPP are expected by UV-R in surface water. According to this relationship, phytoplankton cells characterized by a $\mathrm{PP}^{\mathrm{chl}}$ close to or

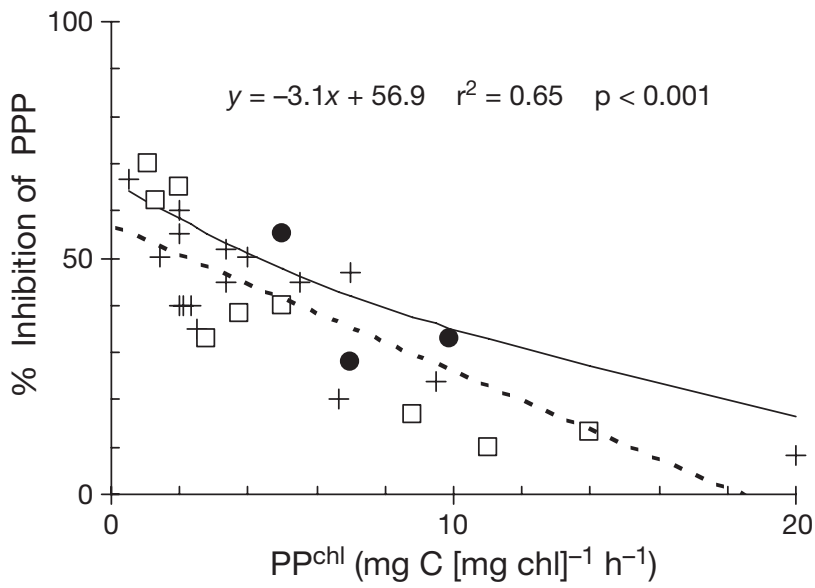

Fig. 10. Relationship between inhibition of particulate primary production (PPP) by UV-R and the rate of primary production normalized by chlorophyll concentration ( $\left.\mathrm{PP}^{\mathrm{chl}}\right)$. Data

(๑) from the present study, ( $\square$ ) Gulf of Lion not published, (+) from literature (Callieri et al. 2001, Helbling et al. 2001, 2003, Neale et al. 2001, Xenopoulos \& Schindler 2003**, Villafãne et al. 2004, Litchman \& Neale 2005**). Equation of the linear regression (dashed line), correlation coefficient and probability are indicated. Solid line corresponds to the $95 \%$ confidence upper limit of the regression. ${ }^{* *} \mathrm{PPP}$ is assimilated to total production because measurements of total production were made by short time incubation $(<1 \mathrm{~h})$ 
higher than $18 \mathrm{mg} \mathrm{C}(\mathrm{mg} \mathrm{chl})^{-1} \mathrm{~h}^{-1}$ should be able to limit UV-R damage and PPP inhibition but may increase DPP. For a similar UV-R dose, PPP of phytoplankton cells characterized by a higher $\mathrm{PP}^{\mathrm{chl}}$ will be inhibited less. It is reasonable to assume that the percentage of PPP inhibition throughout the water column will be distributed below the solid line in Fig. 10 (i.e. corresponding to the higher bound of the $95 \%$ confidence level of the linear regression model). This means that for experimental data above the solid line, an explanation other than UV-R inhibition should be considered. This approach could contribute to partially reconciling the large range of UV-R effect observed for phytoplankton.

Acknowledgements. We thank the crew of the RV 'Dar Mad' for their assistance during sampling and P. Catala and P. Gérard for providing the flow cytometry and nutrient data, respectively. This study was supported by the CNRS-PROOF UVECO project ('Induction of microbial community responses and dissolved organic matter transformation by UltraViolet radiation in marine ECOsystems'), by the French National Research Agency (ANR-ECCO program: 'Role of transparent exopolymeric particles for the transfer of trace metals to the particulate phase') and by the French Research Institute for Development (IRD).

\section{LITERATURE CITED}

Aas P, Lyons MM, Pledger R, Mitchell DL, Jeffrey WH (1996) Inhibition of bacterial activities by solar radiation in nearshore waters and the Gulf of Mexico. Aquat Microb Ecol 11:229-238

Behrenfeld M, Hardy J, Gucinski H, Hanneman A, Lee IIH, Wones A (1993) Effects of ultraviolet-B radiation on primary production along latitudinal transects in the South Pacific Ocean. Mar Environ Res 35:349-363

Briand E, Pringault O, Jacquet S, Torréton JP (2004) The use of oxygen microprobes to measure bacterial respiration for determining bacterioplankton carbon growth efficiency along trophic gradients in a coral reef lagoon. Limnol Oceanogr 2:406-416

Buma AGJ, De Boer MK, Boelen P (2001) Depth distributions of DNA damage in Antarctic marine phyto- and bacterioplankton exposed to summertime UV radiation. J Phycol 37:200-208

Callieri C, Morabito G, Huot Y, Neale PJ, Litchman E (2001) Photosynthetic response of pico- and nanoplanktonic algae to UVB, UVA and PAR in a high mountain lake. Aquat Sci 63:286-293

Carrillo P, Medina-Sanchez JM, Villar-Argaiz M (2002) The interaction of phytoplankton and bacteria in a high mountain lake: importance of the spectral composition of solar radiation. Limnol Oceanogr 47:1294-1306

Conan P, Turley CM, Stutt E, Pujo-Pay M, Van Wambeke F (1999) Relationship between phytoplankton efficiency and the proportion of bacterial production to primary production in the Mediterranean Sea. Aquat Microb Ecol 17: 131-144

Cullen JJ, Neale PJ (1994) Ultraviolet radiation, ozone depletion, and marine photosynthesis. Photosynth Res 39: 303-320
De Mora SJ, Demers S, Vernet M (2000) The effects of UV radiation in the marine environment, Vol 10. Cambridge University Press, Cambridge

> Douki T, Cadet J (2001) Individual determination of the yield of the main-UV induced dimeric pyrimidine photoproducts in DNA suggests a high mutagenicity of CC photolesions. Biochemistry 40:2495-2501

Erga SR, Aursland K, Frette Ø, Hamre B and others (2005) UV transmission in Norwegian marine waters: controlling factors and possible effects on primary production and vertical distribution of phytoplankton. Mar Ecol Prog Ser 305:79-100

Fitzwater SE, Knauer GA, Martin JM (1982) Metal contamination and its effect on primary production measurements. Limnol Oceanogr 27:544-551

Fouilland E, Gosselin M, Mostajir B, Levasseur M, Chanut JP, Demers S, de Mora S (2003) Effects of ultraviolet-B radiation and vertical mixing on nitrogen uptake by a natural planktonic community shifting from nitrate to silicic acid deficiency. Limnol Oceanogr 48:18-30

Fukuda R, Ogawa H, Nagata T, Koike I (1998) Direct determination of carbon and nitrogen contents of natural assemblages in marine environments. Appl Environ Microbiol 64:3352-3358

Garde K, Cailliau C (2000) The impact of UV-B radiation and different PAR intensities on growth, uptake of ${ }^{14} \mathrm{C}$, excretion of DOC, cell volume, and pigmentation in the marine prymnesiophyte, Emiliania huxleyi. J Exp Mar Biol Ecol 247:99-112

> Gieskes WWC, Buma AGJ (1997) UV damage to plant life in a photobiologically dynamic environment: the case of marine phytoplankton. Plant Ecol 128:17-25

Helbling EW, Buma AGJ, De Boer MK, Villafañe VE (2001) In situ impact of solar ultraviolet radiation on photosynthesis and DNA in temperate marine phytoplankton. Mar Ecol Prog Ser 211:43-49

Helbling EW, Gao K, Gonçalves RJ, Wu H, Villafañe VE (2003) Utilization of solar ultraviolet radiation by phytoplankton assemblages from the Southern China Sea when exposed to fast mixing conditions. Mar Ecol Prog Ser 259:59-66

Holm-Hansen O, Lorenzen CJ, Holmes RW, Strickland JDH (1965) Fluorimetric determination of chlorophyll. Cons Perm Int Explor Mer 30:3-15

> Holmes MR, Aminot A, Kérouel R, Hooker BA, Peterson BJ (1999) A simple and precise method for measuring ammonium in marine and freshwater ecosystems. Can J Fish Aquat Sci 56:1801-1808

Jacquet S, Delesalle B, Torréton JP, Blanchot J (2006) Response of phytoplankton communities to increased anthropogenic influences (southwestern lagoon, New Caledonia). Mar Ecol Prog Ser 320:65-78

Jeffrey W, Kase JP, Whilhem SW (2000) UV radiation effects on heterotrophic bacterioplankton and viruses in marine ecosytems. In: De Mora S, Demers S, Vernet M (eds) The effects of UV radiation in the marine environment. Cambridge University Press, Cambridge, p 206-236

Jouon A, Douillet P, Ouillon S, Fraunié P (2006) Calculations of hydrodynamic time parameters in a semi-opened coastal zone using a 3D hydrodynamic model. Cont Shelf Res 26:1395-1415

Kaiser E, Herndl GJ (1997) Rapid recovery of marine bacterioplankton activity after inhibition by UV radiation in coastal waters. Appl Environ Microbiol 63:4026-4031

Karentz D, Cleaver JE, Mitchell DL (1991) Cell survival characteristics and molecular responses of Antarctic phytoplankton to ultraviolet-B radiation. J Phycol 27:326-341 
Litchman E, Neale PJ (2005) UV effects on photosynthesis, growth and acclimation of an estuarine diatom and cryptomonad. Mar Ecol Prog Ser 300:53-62

Mari X, Rochelle-Newall EJ, Torréton JP, Pringault O, Jouon A, Migon C (2007) Water residence time: a regulatory factor of the DOM to POM transfer efficiency. Limnol Oceanogr 52:808-819

Mengelt C, Prézelin BB (2005) UVA enhancement of carbon fixation and resilience to UV inhibition in the genus Pseudo-nitzschia may provide a competitive advantage in high UV surface waters. Mar Ecol Prog Ser 301:81-93

Morán XAG, Gasol JM, Arin L, Estrada M (1999) A comparison between glass fiber and membrane filters for the estimation of phytoplankton POC and DOC production. Mar Ecol Prog Ser 187:31-41

Mostajir B, Demers S, De Mora S, Belzile C and others (1999) Experimental test of the effect of ultraviolet-B radiation in a planktonic community. Limnol Oceanogr 44:586-596

Neale PJ, Litchman E, Sobrino C, Callieri C and others (2001) Quantifying the response of phytoplankton photosynthesis to ultraviolet radiation: biological weighting functions versus in situ measurements in two Swiss lakes. Aquat Sci 63:265-285

> Nielsen T, Ekelund NGA (1995) Influence of solar ultraviolet radiation on photosynthesis and motility of marine phytoplankton. FEMS Microbiol Ecol 18:281-288

Obernosterer I, Sempéré R, Herndl GJ (2001) Ultraviolet radiation induces reversal of the bioavailability of DOM to marine bacterioplankton. Aquat Microb Ecol 24:61-68

Piazena H, Perez-Rodrigues E, Häder DP, Lopez-Figueroa F (2002) Penetration of solar radiation into the water column of the central subtropical Atlantic Ocean - optical properties and possible biological consequences. Deep-Sea Res 49:3513-3528

Renaud F, Pringault O, Rochelle-Newall E (2005) Effects of the colonial cyanobacterium Trichodesmium spp. on bacterial activity. Aquat Microb Ecol 41:261-270

Rochelle-Newall EJ, Torréton JP, Mari X, Pringault O (2008) Phytoplankton-bacterioplankton coupling in a subtropical South Pacific coral reef lagoon. Aquat Microb Ecol 50: 221-229

Smith DC, Azam F (1992) A simple, economical method for measuring bacterial protein synthesis rates in seawater using ${ }^{3} \mathrm{H}$-leucine. Mar Microb Food Webs 6:107-114

Smith RC, Cullen JJ (1995) Effects of UV radiation on phytoplankton. Rev Geophys 33:1211-1224

Editorial responsibility: Josep Gasol,

Barcelona, Spain
Sommaruga R, Obernosterer I, Herndl GJ, Psenner R (1997) Inhibitory effect of solar radiation on thymidine and leucine incorporation by freshwater and marine bacterioplankton. Appl Environ Microbiol 63:4178-4184

Tedetti M, Sempéré R (2006) Penetration of ultraviolet radiation in the marine environment: a review. Photochem Photobiol 82:389-397

Torréton JP, Rochelle-Newall EJ, Jouon A, Faure V, Jacquet S, Douillet P (2007) Correspondence between the distribution of hydrodynamic time parameters and the distribution of biological and chemical variables in a semi-enclosed coral reef lagoon. Estuar Coast Shelf Sci 74:766-776

Tréguer P, Le Corre P (1975) Manuel d'analyses des sels nutritifs dans l'eau de mer. Laboratoire d'Océanographie Chimique. Université de Bretagne Occidentale, Brest

UNEP (2006) Environmental effects of ozone depletion and its interactions with climate change: progress report, 2005. Photochem Photobiol Sci 5:13-24

- Villafañe VE, Helbling EW, Holm-Hansen O, Chalker BE (1995) Acclimatization of Antarctic natural phytoplankton assemblages when exposed to solar ultraviolet radiation. J Plankton Res 17:2295-2306

> Villafãne VE, Barbieri ES, Helbling EW (2004) Annual patterns of ultraviolet radiation effects on temperate marine phytoplankton off Patagonia, Argentina. J Plankton Res 26:167-174

Vincent WF, Neale PJ (2000) Mechanisms of UV damage to aquatic organisms. In: De Mora SJ, Demers S, Vernet $M$ (eds) The effects of UV radiation in the marine environment. Cambridge University Press, Cambridge, p $149-176$

- Visser PM, Poos JJ, Scheper BB, Boelen P, Van Duyl FC (2002) Diurnal variations in depth profiles of UV-induced DNA damage and inhibition of bacterioplankton production in tropical coastal waters. Mar Ecol Prog Ser 228:25-32

> Wängberg SA, Selmer JS, Gustavson K (1998) Effects of UV-B radiation on carbon and nutrient dynamics in marine plankton communities. J Photochem Photobiol 45:19-24

Wood ED, Armstrong FA, Richards FA (1967) Determination of nitrate in sea water by cadmium copper reduction to nitrite. J Mar Biol Assoc UK 47:23-31

Xenopoulos MA, Schindler DW (2003) Differential responses to UVR by bacterioplankton and phytoplankton from the surface and the base of the mixed layer. Freshw Biol 48:108-122

Submitted: November 29, 2007; Accepted: April 11, 2008

Proofs received from author(s): June 27, 2008 